\title{
Soil structure changes induced by tillage systems
}

\author{
Luiz F. Pires ${ }^{\mathrm{a}, *}$, Jaqueline A.R. Borges ${ }^{\mathrm{a}, *}$, Jadir A. Rosa ${ }^{\mathrm{b}}$, Miguel Cooper ${ }^{\mathrm{c}}$, Richard J. Heck ${ }^{\mathrm{d}}$, \\ Sabrina Passoni ${ }^{a}$, Waldir L. Roque ${ }^{\mathrm{e}}$ \\ a Department of Physics, State University of Ponta Grossa, 84030-900 Ponta Grossa, PR, Brazil \\ ${ }^{\mathrm{b}}$ Laboratory of Soil Physics, Agricultural Research Institute of Paraná, 84001-970 Ponta Grossa, PR, Brazil \\ ${ }^{\mathrm{c}}$ Department of Soil Science, Luiz de Queiroz College of Agriculture, State University of São Paulo,13418-900 São Paulo, SP, Brazil \\ d Department of Land Resource Science, Department of Land Resource Science, University of Guelph, N1G2W1 Guelph, ON, Canada \\ e Department of Scientific Computation, Informatics Center, Federal University of Paraíba, 58051-900 João Pessoa, PB, Brazil
}

\section{A R T I C L E I N F O}

\section{Article history:}

Received 19 April 2016

Received in revised form 12 July 2016

Accepted 15 July 2016

Available online 5 August 2016

\section{Keywords:}

Soil porous system

Microtomography

Soil water retention curve

\begin{abstract}
A B S T R A C T
Structure represents one of the main soil physical attributes indicators. The soil porous system (SPS) is directly linked to the soil structure. Water retention, movement, root development, gas diffusion and the conditions for all soil biota are related to the SPS. Studies about the influence of tillage systems in the soil structure are important to evaluate their impact in the soil quality. This paper deals with a detailed analysis of changes in the soil structure induced by conventional (CT) and no-tillage (NT) systems. Three different soil depths were studied $(0-10,10-20$ and $20-30 \mathrm{~cm})$. Data of the soil water retention curve (SWRC), micromorphologic (impregnated blocks) (2D) and microtomographic ( $\mu \mathrm{CT}$ ) (3D) analyses were utilized to characterize the SPS. Such analyses enabled the investigation of porous system attributes such as: porosity, pore number and shape, pore size distribution, tortuosity and connectivity. Results from this study show a tri-modal pore size distribution (PSD) at depths $0-10$ and $10-20 \mathrm{~cm}$ for the soil under CT and a bi-modal PSD for the lower layer $(20-30 \mathrm{~cm})$. Regarding the soil under NT, tri-modal PSDs were found at the three depths analyzed. Results based on the micromorphologic analysis (2D) showed that the greatest contribution to areal porosity (AP) is given by pores of round (R) shape for CT $(52 \%$ : $0-10 \mathrm{~cm}$; $50 \%$ : 10 $20 \mathrm{~cm} ; 67 \%: 20-30 \mathrm{~cm}$ ). Contrary to the results observed for CT, the soil under NT system gave the greatest contribution to AP, for the upper $(0-10 \mathrm{~cm})$ and intermediate $(10-20 \mathrm{~cm})$ layers, due to the large complex (C) pore types. For the $\mu \mathrm{CT}$ analysis, several types of pores were identified for each soil tillage system. Small differences in the macroporosity (MAP) were observed for the $0-10$ and $20-30 \mathrm{~cm}$ between CT and NT. A better pore connectivity was found for the $0-10 \mathrm{~cm}$ layer under NT.
\end{abstract}

(c) 2016 Elsevier B.V. All rights reserved.

\section{Introduction}

Water infiltration and retention are directly affected by the soil porous system (SPS) (Kodešová et al., 2011; Pagliai and Vignozzi, 2002). The transmission of water through the soil is important for the plant development and also to avoid environmental problems such as erosion. The water retention is important to supply water for plants, to stabilize the soil temperature and to maintain soil stability (Lipiec et al., 2006).

Pore size distribution (PSD) and its continuity control the water infiltration and retention (Hillel, 1998; Kutílek and Nielsen, 1994).

\footnotetext{
* Corresponding authors at: Departamento de Física, Universidade Estadual de Ponta Grossa, Campus de Uvaranas, Bloco L, Sala 15B; Av. Carlos Cavalcanti, 4748, CEP 84.030-900 Ponta Grossa, PR, Brasil.

E-mail addresses: luizfpires@gmail.com (L.F. Pires), jaqueribaski@gmail.com, jaqueribaski@hotmail.com (J.A.R. Borges).
}

Pores of different sizes present distinct functions in the soil. Pores with equivalent cylindrical diameter $(\mathrm{ECD})>50 \mu \mathrm{m}$ are classified as transmission pores and $<0.50 \mu \mathrm{m}$ as residual + bonding pores. While the former is responsible for air movement and drainage of excess water, the latter provides retention and diffusion of ions in solutions. The intermediate pore size between 0.50 and $50 \mu \mathrm{m}$ is responsible for the retention of water against gravity and release (Lal and Shukla, 2004).

The use of PSD to infer soil structure changes induced by different phenomena is becoming more and more common in the soil science (Cássaro et al., 2011; Dal Ferro et al., 2014). The methods utilized to obtain pore size distribution are based on the soil water retention curve (SWRC), mercury porosimetry, nitrogen adsorption and image analysis techniques such as the conventional resin impregnated block methodology or computed microtomography ( $\mu C T$ ) (Hajnos et al., 2006; Imhoff et al., 2010; Kutilek et al., 
2006; Lipiec et al., 2007; Ogunwole et al., 2015; Pagliai et al., 2004; Pires et al., 2013; Rab et al., 2014; Taina et al., 2010).

The derivative of the SWRC is used for the indirect computation of PSD. On the other hand, methods based on image analysis allow the direct SPS characterization in 2D (impregnated blocks) and 3D $(\mu \mathrm{CT})$ with spatial resolutions from centimeters to micrometers (Helliwell et al., 2013; Pires et al., 2010).

The $\mu \mathrm{CT}$ is interesting because it is a non-invasive technique that allows the soil pores characterization of macro aggregates and micro aggregates (Brown et al., 2014; Dal Ferro et al., 2012; Pagenkemper et al., 2015). Among the different pore sizes, macropores have, as their main function, a fast drainage of water under saturation condition (Allaire-Leung et al., 2000; Anderson et al., 2010; Guérif et al., 2001). The number, volume, shape, orientation, continuity, tortuosity and macropore size distribution control the intake rate of water drainage and solute flux processes, such as the hydraulic conductivity (Amer et al., 2009; Kutílek, 2004).

Tillage systems present great influence in the SPS and consequently in the PSD (Kay and VandenBygaart, 2002; Kravchenko et al., 2011; Peth et al., 2008; Schjønning and Rasmussen, 2000). Tavares Filho and Tessier (2009) observed important changes in the structure of a Brazilian Oxisol induced by conventional (CT) and no-tillage (NT) systems. The authors observed a disaggregated microaggregate structure between 0 and $20 \mathrm{~cm}$ for CT and the presence of fissures and biopores for NT. The volume of pores with ECD $>100 \mu \mathrm{m}$ was practically nonexistent under $\mathrm{CT}$ and those $<100 \mu \mathrm{m}$ were practically not affected by the type of soil management. Portella et al. (2012), also working with a Brazilian Oxisol, described changes in the aggregate stability index, mean weighted diameter and mean geometric diameter induced by the tillage systems. More intense soil preparation (CT) resulted in a decrease in soil stability, which directly affected the SPS.

Thus, the study of micromorphological attributes of the soil pore system has shown to be quite relevant, particularly concerned to the SPS, as it is important to the transport and drainage of solutes (Hillel, 1998; Kodesova' et al., 2008). Knowledge about how the pore shape, connectivity, anisotropy and alignment along the sample volume, in conjunction with porosity, PSD and other features is essential to define, with improved precision, the soil structure and its physical attributes, foreseeing the physicalhydraulic behavior along the transversal directions as well as in depth.

Therefore, the main goal of this work was to investigate and explore several tools to characterize the changes in the soil porous system, caused by conventional and no-tillage systems, at three different soil depths. Pore size distributions derived from soil water retention data and image analysis techniques were utilized. Pore shape, size distribution and its connectivity and tortuosity were analyzed. This study is a first report of a detailed analysis of changes in the structure of Brazilian soil due to tillage systems at different scales.

\section{Material and methods}

\subsection{Experimental area and soil samples}

This study was carried out with samples collected on the experimental farm of the Agricultural Research Institute of Parana (IAPAR) in the city of Ponta Grossa, PR, Brazil $\left(25^{\circ} 06^{\prime} \mathrm{S}, 50^{\circ} 10^{\prime} \mathrm{W}\right.$, $875 \mathrm{~m}$ above sea level). The soil under investigation is classified as Red Latosol according to the Brazilian Soil Classification System (EMBRAPA, 2013); Oxisol (Typic Haplorthox) according to the USDA soil taxonomy (Soil Survey Staff, 1998); and Rhodic Ferralsol
Table 1

Characteristics of the soil studied for the different tillage systems.

\begin{tabular}{llllllll}
\hline Property & $\mathrm{CT}$ & & & & $\mathrm{NT}$ \\
\cline { 2 - 3 } \cline { 7 - 8 } & $0-10$ & $10-20$ & $20-30$ & & $0-10$ & $10-20$ & $20-30$ \\
\hline Clay $\left(\mathrm{g} \mathrm{kg}^{-1}\right)$ & & 610 & & & 650 & \\
Silt $\left(\mathrm{g} \mathrm{kg}^{-1}\right)$ & & 220 & & & 240 & \\
Sand $\left(\mathrm{g} \mathrm{kg}^{-1}\right)$ & & 170 & & & 110 & \\
TP $(\%)$ & 55.8 & 51.7 & 51.7 & & 60.2 & 54.5 & 57.1 \\
Ma (\%) & 12.5 & 7.7 & 8.1 & & 12.7 & 11.0 & 10.8 \\
Mi (\%) & 43.3 & 44.0 & 43.6 & & 47.6 & 43.5 & 46.3 \\
\hline
\end{tabular}

Textural (clay, silt, sand) analysis at the $0-10 \mathrm{~cm}$ depth; TP: total porosity; Ma: macroporosity; Mi: microporosity ( $\mathrm{h}=100 \mathrm{~cm}$ of water); $\mathrm{CT}$ : conventional tillage; NT: no-tillage.

according to FAO classification (FAO, 1998). Based on textural analysis the soil was classified as having clay texture (Table 1 ).

The climate in the region, according to the Köeppen classification, is a humid mesothermal Cfb-subtropical with mild summers. The annual average rainfall is approximately $1550 \mathrm{~mm}$, with a maximum average annual temperature of $22^{\circ} \mathrm{C}$ and minimum $18^{\circ} \mathrm{C}$, with frost occurrence in the coldest months (June-August).

Soil samples were collected from two areas, one submitted to NT $\left(10,000 \mathrm{~m}^{2}\right)$ and the other to CT $\left(6000 \mathrm{~m}^{2}\right)$. Both tillage systems have been used in the areas for over 25 years. NT has been conducted continuously in the area for 26 years. In these areas, crop rotation is practiced, with cover crops such as oats or vetch in winters and corn or soybeans in summers. In addition to practices for planting and cleaning, CT is also submitted to disk plowing (up to $25 \mathrm{~cm}$ ) followed by 2 harrowing procedures.

For SWRC evaluation, soil samples $(n=5)$ were collected in volumetric rings $(5.0 \mathrm{~cm}$ high and $4.8 \mathrm{~cm}$ internal diameter) made of steel in 2010. The undisturbed soil samples were collected using a cylindrical Uhland sampler. The soil excess outside the cylinder was carefully trimmed off and top and bottom surfaces of the sample were made flat to be sure that the soil volume was equal to the internal volume of the cylinder. Since the soil water content is very important at sampling time to minimize impact effects, samples were collected near their plastic limit, about three days after a high intensity rainfall event (approximately $50 \mathrm{~mm}$ ).

For the micromorphologic analysis of impregnated blocks, soil samples $(\mathrm{n}=3)$ were collected in 2012 as blocks of approximately $345 \mathrm{~cm}^{3}(7 \times 7 \times 7 \mathrm{~cm})$. Small trenches were opened in the experimental field and the sample blocks were carefully handcut with the use of special knifes and palette knifes. After sampling, the samples were wrapped in foil.

For $\mu \mathrm{CT}$ analysis, trenches were opened and soil blocks $(n=3)$ were carefully extracted in 2013 by using palette knifes (approximately $20 \times 20 \times 10 \mathrm{~cm}$ ). After sampling, the samples were wrapped in foil. The blocks were thoroughly molded and later placed into acrylic tubes of $6.4 \mathrm{~cm}$ internal diameter and $15.0 \mathrm{~cm}$ height.

Sampling was carried out after harvest (normally ryegrass Lolium multiflorium) in all the procedures described. Three different soil depths were sampled: $0-10,10-20$ and $20-30 \mathrm{~cm}$.

\subsection{Soil water retention curve}

SWRC data were obtained by using a commercial tension table (Eijkelkamp) $(10 ; 30 ; 40 ; 60$ and $80 \mathrm{~cm}$ of water) and commercial pressure extraction vessels (Soil Moisture Equipment Co.) (100; $330 ; 500 ; 800 ; 1000 ; 4000 ; 8000$ and $15,000 \mathrm{~cm}$ water).

The wetting procedure to saturate the samples consisted in soaking them using a tray with the water level just below the top of the cylinders. This procedure is carried out over a period of 1 or 2 days to allow saturation of the soil and to avoid the presence of the entrapped air bubbles. After the wetting procedure soil 
samples were placed in contact with the porous plate inside a pressure chamber and air pressure was applied. After the thermodynamic equilibrium, the gravimetric water content was obtained and later on converted into the volumetric water content $(\theta)$ (Hillel, 1998). Details about SWRC evaluation can be found in Klute (1986).

Data of $\theta(h)$ was transformed into its parametric form $S(h)$, relative saturation, and a cubic spline function was used to fit the experimental data of $\mathrm{S}(\mathrm{h})$ versus $\ln$ h resulting in a smooth curve (Kastanek and Nielsen, 2001; Kutilek et al., 2006). Water pressure heads were converted to the pore radius ( $\mathrm{r}$ ) using the relation $r=1490 / h$, with $r$ and $h$ given in $\mu \mathrm{m}$ and $\mathrm{cm}$, respectively (Kutílek and Nielsen, 1994). After this transformation dS*(lnh)/dlnh versus $\operatorname{lnr}$ represented the pore size distribution plots.

\subsection{Micromorphological analysis (impregnated blocks)}

The impregnation of the samples was performed under vacuum using a non-saturated polyester resin (Crystic SR 17449) mixed with a styrene monomer. Fluorescent pigments (Unitex $\mathrm{OB}$ ) were added to the solution to allow for the distinction among the pores when lit with fluorescent light. A period of about six weeks was necessary to harden the impregnated soil samples. After this period, they were cut in rectangular slices, vertically oriented; having one of their faces polished for image analysis procedures.

Digital images were acquired from impregnated blocks using a color CCD camera with a resolution of $1024 \times 768$ pixels (area of $100 \mu \mathrm{m}^{2}$ pixel $^{-1}$ ) coupled to a petrographic microscope with $\mathrm{a} \times 10$ optical lens. The images were processed and analyzed using the Noesis-Visilog ${ }^{\mathbb{R}} 5.4$ image analysis software.

The selected soil samples areal porosity (AP) was evaluated dividing the total area of the selected cross-section of the void space (assumed as pores) by the total sample area and it was expressed as a percentage (Pires et al., 2008). AP and pore distribution were measured according to the shape and size. Pore areas were characterized according to their shape and size, using three major shape groups: rounded (R), elongated (E), and complex (C), characterized through two indexes and thresholds (Cooper et al., 2005) (Table 2).

The first index used to characterize the pore shape was the following:

$I_{1}=\frac{P^{2}}{4 \pi A}$

where $P$ represents the perimeter of the pore area and $A$ its area.

The second index gives information about the pore shape (Cooper et al., 2005):

$I_{2}=\frac{\frac{1}{m} \sum_{i}\left(N_{I}\right)_{i}}{\frac{1}{n} \sum_{j}\left(D_{F}\right)_{j}}$

where, $\mathrm{N}_{\mathrm{I}}$ is the number of intercepts of the object in the direction $\mathrm{i}$ $\left(\mathrm{i}=0^{\circ}, 45^{\circ}, 90^{\circ}\right.$ and $\left.135^{\circ}\right), \mathrm{D}_{\mathrm{F}}$ is the Feret diameter of an object in the direction $\mathrm{j}\left(\mathrm{j}=0^{\circ}\right.$ and $\left.90^{\circ}\right), \mathrm{m}$ is the number of $\mathrm{i}$ directions and $\mathrm{n}$ is the number of $j$ directions. $R$ pores were characterized using index

Table 2

Pore area classification according to shape.

\begin{tabular}{llll}
\hline Shape indexes & \multicolumn{3}{l}{ Pore Types } \\
\cline { 2 - 4 } & $\mathrm{R}$ & $\mathrm{E}$ & $\mathrm{C}$ \\
\hline $\mathrm{I}_{1}$ & $\leq 5$ & $5<\mathrm{I}_{1} \leq 25$ & $5<\mathrm{I}_{1} \leq 25$ or $>25$ \\
$\mathrm{I}_{2}$ & - & $\leq 2.2$ & $>2.2$ \\
\hline
\end{tabular}

R: rounded; E: elongated; C: complex.
$\mathrm{I}_{1}$. Indexes $\left(\mathrm{I}_{1}\right)$ and $\left(\mathrm{I}_{2}\right)$ were used to classify E pores. For values of $I_{1}>25$, the pores were characterized as $C$, regardless of their $I_{2}$ values.

After particle analyses, the file with the data was moved to an spreadsheet in which pores with areas ranging from 0 to $>156,000$ $\mu \mathrm{m}^{2}$ were analyzed. According to the dimensions of their areas, soil pores were classified as small (S) (156-15,600 $\left.\mathrm{mm}^{2}\right)$, medium (M) $\left(15,601-156,000 \mu \mathrm{m}^{2}\right)$ and large $(\mathrm{L})\left(>156,000 \mu \mathrm{m}^{2}\right)$.

\subsection{Micromorphological analysis ( $\mu C T)$}

Samples were imaged with an MS8x-130 X-ray microtomograph (EVS/GE Medical $\mu C T)$. The scans were performed at the central region of the cylinder. The image resolution acquisition was $20 \mu \mathrm{m}$ (isotropic voxel), which resulted in a set of $7202 \mathrm{D}$ slices for each sample.

Regions of interest (ROI) of $650 \times 650 \times 550$ voxels were selected from the center of the set of images, excluding the borders, using the software GEHC Microview (GE Healthcare, 2006). The pre-processing and processing steps were developed according to the protocol of the Soil Image Laboratory, University of Guelph, CA (Jefferies et al., 2014; Taina et al., 2013).

Firstly, the image reconstruction process was carried out using the filtered back-projection algorithm (Buzug, 2008). The spatial resolution adopted for reconstruction was $60 \mu \mathrm{m}$, which resulted in a set of images of $39 \times 39 \times 33 \mathrm{~mm}$. Then, a local Gaussian filter was applied in order to reduce noise in the images. Further, to minimize the noise concerning the ring artifacts on $\mu \mathrm{CT}$ images, they were submitted to a treatment using a special purpose plugin for ImageJ (Heck, 2009).

The segmentation process was based on the shades of gray histograms of each image set, following the methodology described in Elliot and Heck (2007), Jefferies et al. (2014) and Schlüter et al. (2010). Such process resulted in a binary image, in which pores and grains were respectively represented by white and black pixels.

For the 3D structure study, the pores were characterized regarding the main axes number, volume and dimensions (major, intermediate and minor). Based on this analysis, each pore was assigned to an identifier number, varying from 1 to 65,536 (16 bits image) (Heck, 2009; Jefferies et al., 2014; Rasband, 2007).

Once the spatial resolution for images reconstruction was $60 \mu \mathrm{m}$, only pores $\mathrm{r} \geq 30 \mu \mathrm{m}$ were detected. Such pores compose part of the soil macroporosity (MAP) (EMBRAPA, 1997). For $\mu C T$ images, the MAP is given by Eq. (3):

$\mathrm{MAP}=\frac{\mathrm{V}_{\mathrm{p}}}{\mathrm{V}_{\mathrm{t}}}$

where $V_{p}$ represents the volume of void voxels and $V_{t}$ is the total sample volume (void plus solid voxels).

The MAP and number of macropores (NMAP) were calculated taking into consideration the image resolution. The NMAP corresponded to the total number of disconnected macropores inside the total sample volume. For MAP and NMAP distribution analyses, the macropores were classified at different volume intervals: $0-0.001 ; 0.001-0.01 ; 0.01-0.1 ; 0.1-1 ; 1-10 ; 10-100$; $100-1000$ and $>1000 \mathrm{~mm}^{3}$.

The pore shape analyses were carried out for pores $0.002-$ $32.4 \mathrm{~mm}^{3}\left(8-15 \times 10^{4}\right.$ voxels), according to Jefferies et al. (2014). Such segregation is justified due to the voxels arrangement, mostly it was not possible to measure the axes size for pores $\leq 8$ voxels. In turn, pores $\geq 15 \times 10^{4}$ voxels are associated to several branching and irregular shape.

The macropores which allowed the measurement of the three principal axes were classified according to the proposal first elaborated by Zingg, in 1935, and improved by Brewer, in 1964. The 
terminology suggested by Bullock et al. (1985) was adopted. Thus, the pores were classified as Equant (Eq.), Prolate (Pr.), Oblate (Ob.), Triaxial (Tr.), Planar (Pl.), Acircular (Ac.) or Acircular-Planar (AP). When one of the axes of a specific pore could not be determined by the software, this pore was not classified according to its shape. In such case, it was called unclassified pore (UN).

The pore network tortuosity $(\tau)$ and connectivity were analyzed using a computer program called Osteolmage (Arcaro, 2013; Roque et al., 2009). $\tau$ was computed assuming the geodesic reconstruction algorithm implemented by Roque et al. (2012a,b):

$\tau=\frac{\mathrm{L}_{\mathrm{G}}}{\mathrm{L}_{\mathrm{E}}}$

where $L_{G}$ is the geodesic length between two connected points within the pore space and $L_{E}$ is the Euclidian length joining these points. In this study, the average tortuosity was considered, which resulted from a tridimensional analysis.

The connectivity degree was estimated based on the EulerPoincaré characteristic (EPC). In simple terms, EPC for a 3D structure is defined as the number of isolated parts minus the connectivity of an object (Thurston, 1997). The linear correlation for the set of EPC values with respect to the contiguous image sections, known as disectors (Sterio, 1984), was obtained considering 549 disectors. Once estimated the EPC for each disector of a sample, the sum of EPC values gives an estimate of the connection of the sample; however, it is more convenient to obtain the EPC per sample volume (Roque et al., 2012b). According to the EPC, highly connected structures present small and negative values (Chappard et al., 1999) while low connected structures present high positive values (Roque et al., 2009).

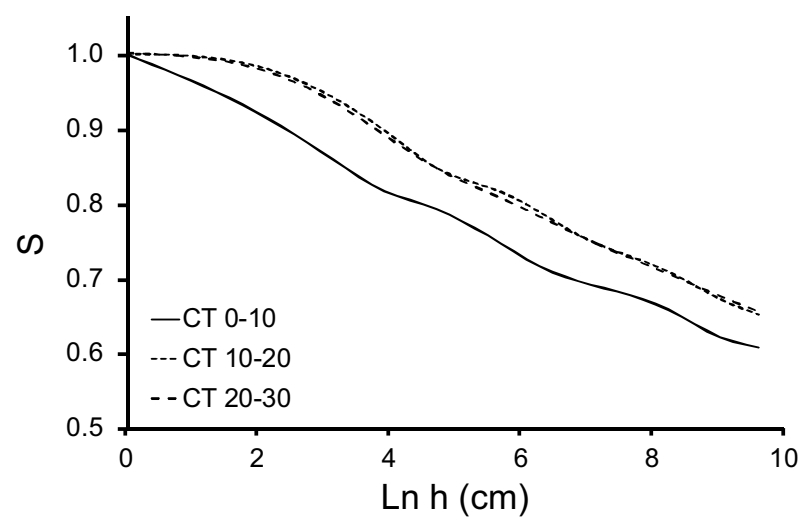

(a)

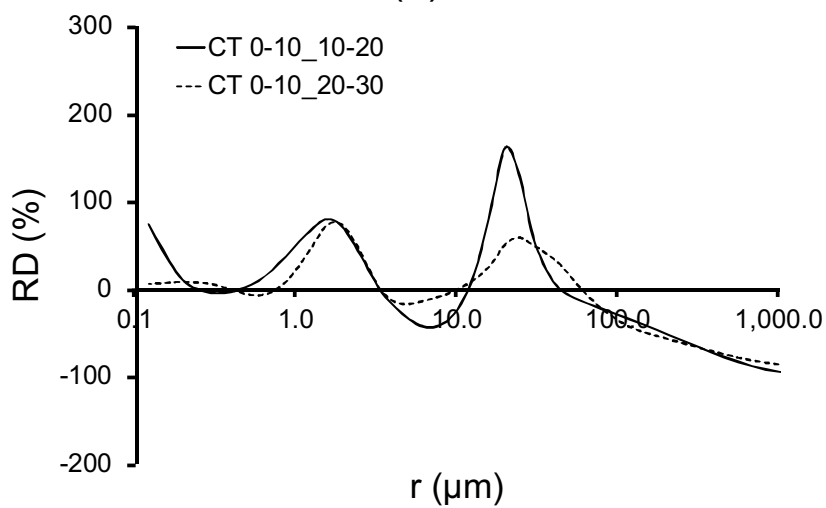

(c)

\section{Results and discussion}

\subsection{SWRC and pore size distribution}

The derivative of SWRC adjusted through the cubic spline function (Kastanek and Nielsen, 2001) demonstrated the presence of textural and structural domains for both tillage systems (Figs. 1 and 2).

For CT, SWRCs showed similarities for the depth of 10-20 and $20-30 \mathrm{~cm}$, which differed from the surface layer $(0-10 \mathrm{~cm})$ analyzed (Fig. 1a). Greater values of air-filled porosity $(\varphi)$ were observed for the small pore sizes at the surface layer in relation to the other layers (Fig. 1d). This result was directly related to the largest TP found for this layer (Table 1 ), which was induced by the soil disturbance (Osunbitan et al., 2005). Under CT, the microaggregate structure was disaggregated favoring an increase in TP in the surface layer (Tavares Filho and Tessier, 2009). The soil structure was pulverized under CT and the clods were broken leading to an increase in Ma (Table 1) (Kay and VandenBygaart, 2002).

The separation between the textural (matrix) and structural domains was similar among layers and corresponded to pore radius of about $1.1 \mu \mathrm{m}$ for the upper layer and $0.7 \mu \mathrm{m}$ for the remaining layers (Fig. 1b). This value was different from those reported by Kutilek et al. (2006), which indicated an interval from 2.5 to $10.9 \mu \mathrm{m}$ for distinct soil textures. However, these authors' analyses were carried out with soils of temperate regions. However, according to Tuller and Or (2002) the matrix domain is composed by small pore sizes in the range of $10-0.1 \mu \mathrm{m}$.

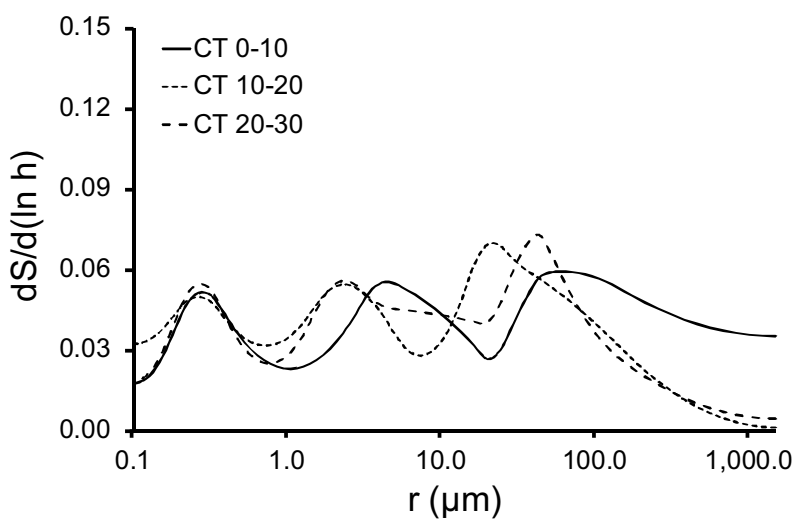

(b)

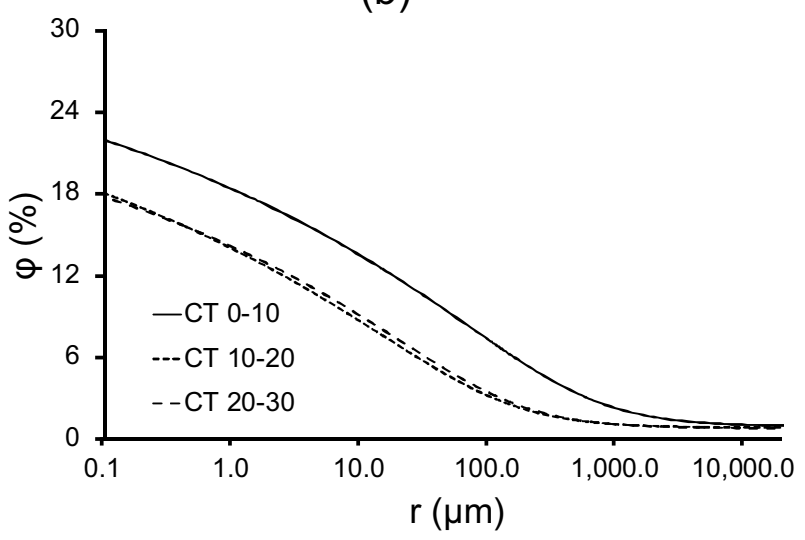

(d)

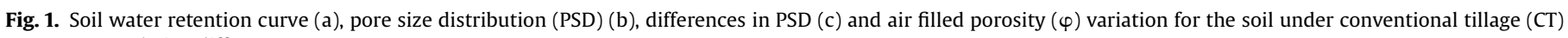
system. RD: relative difference. 


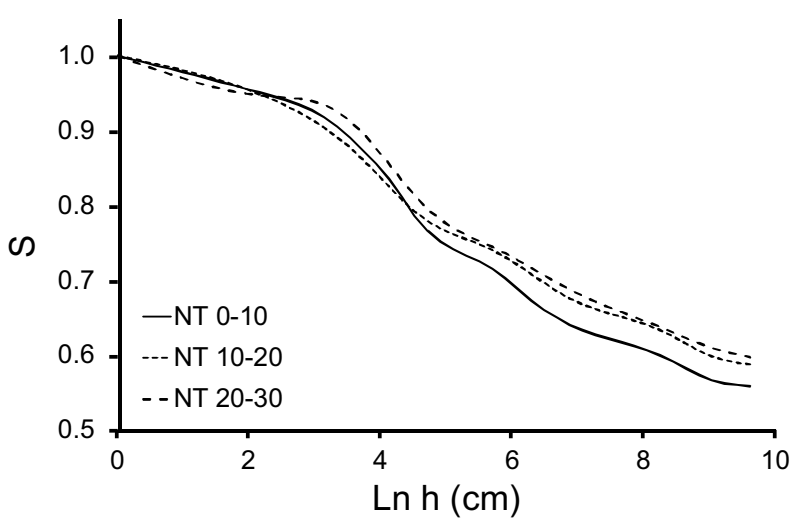

(a)

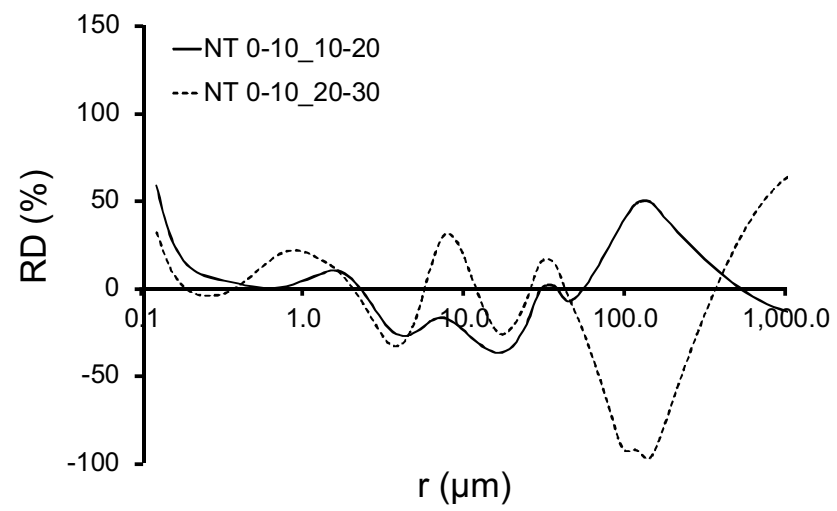

(c)

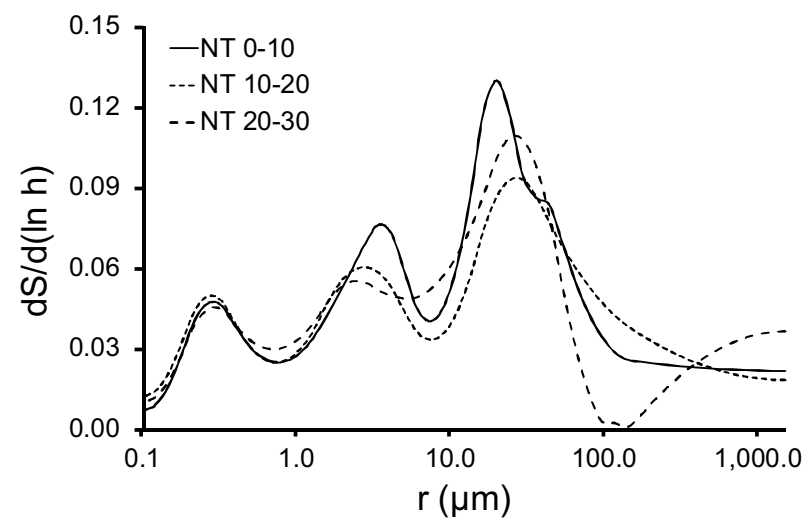

(b)

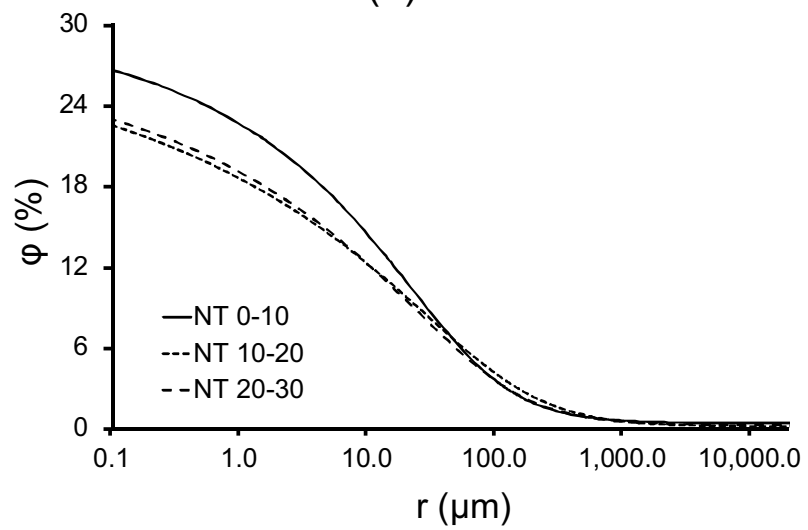

(d)

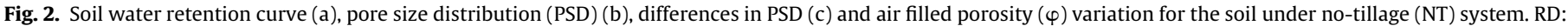
relative difference.

For the $0-10$ and $10-20 \mathrm{~cm}$, a tri-modal PSD was observed with peaks in $0.3 \mu \mathrm{m}$ (matrix domain), $4.1 \mu \mathrm{m}$ and $65 \mu \mathrm{m}$ (structural domain) for the $0-10 \mathrm{~cm}$ layer and $0.3 \mu \mathrm{m}$ (matrix domain), $2.3 \mu \mathrm{m}$ and $20 \mu \mathrm{m}$ (structural domain) for the $10-20 \mathrm{~cm}$ layer, respectively (Fig. 1b). For the lowest layer $(20-30 \mathrm{~cm})$, a bi-modal PSD was observed with peaks in $0.3 \mu \mathrm{m}$ (matrix domain) and $44 \mu \mathrm{m}$ (structural domain). Lipiec et al. (2006) and Ogunwole et al. (2015) also found bi-modal and tri-modal PSDs for soils under different tillage systems.

Changes in PSD due to CT occurred mainly for pore radius larger than $1.0 \mu \mathrm{m}$ for the $10-20$ and $20-30 \mathrm{~cm}$ in relation to the upper layer with the largest modifications being observed in the structural domain pore range (Fig. 1c).

Regarding the NT system, similarities were observed in the SWRCs among layers (Fig. 2a). This result was mainly related to the conservationist nature of NT. This system stimulates a diversity of microorganisms, thereby improving the organic matter of the soil. These factors consequently contribute to the development of a more stable structure of the soil, which in turn helps minimize environmental degradation (Alvarez and Steinbach, 2009). Similarities in the Ma values among layers are an indication of this structure being more stable and the highest Ma, in the upper layer, is a consequence of organic matter accumulation as observed by Martins et al. (2011) for the same soil and studied area (Table 1). As observed for CT, greater values of $\varphi$ were observed for the small pore sizes at the surface layer in relation to the other layers for NT (Fig. 2d). Again, the largest TP found for this layer helps to explain this result. It is important to observe that $\varphi$ values were practically the same up to a pore radius of around $90 \mu \mathrm{m}$.
The separation between the textural and structural domains was practically the same among layers and corresponded to pore radius of about $0.7 \mu \mathrm{m}$ (Fig. 1b). Tri-modal PSDs were observed with peaks in $0.3 \mu \mathrm{m}$ in the matrix domain for all the layers studied; and in $3.4 \mu \mathrm{m}$ and $20 \mu \mathrm{m}(0-10 \mathrm{~cm}), 2.8 \mu \mathrm{m}$ and $29 \mu \mathrm{m}$ $(10-20 \mathrm{~cm})$ and $2.3 \mu \mathrm{m}$ and $24 \mu \mathrm{m}(20-30 \mathrm{~cm})$ in the structural domain. The most important differences among layers were observed for the second peak (range from 5 to $100 \mu \mathrm{m}$ ) in the structural domain (Fig. 2c).

\subsection{Micromorphological analysis (impregnated blocks)}

In order to characterize the PSD through 2D image analysis, average values of AP and total number of pores (TNP), as a function of the shape and size of the pores, were obtained for CT and NT (Figs. 3 and 4).

Regarding the CT system, the AP varied about $22 \%$ between the upper and the lower layer studied (Table 3). However, the reduction in AP was not followed by a reduction in TNP. TNP increased for the lower layer $(20-30 \mathrm{~cm})$. A decrease in the contribution of large $C$ pores to AP occurred with depth (Figs. 3a,c, e), which was associated to the soil disturbance. The contribution of $\mathrm{R}$ pores of different sizes was practically not affected by CT. This means that this pore type is more stable to changes in the SPS, mainly the small ones (Hillel, 1998). The contribution of E pores suffered only a slight decrease among layers with depth.

The largest contribution to AP belonged to R-shaped pores for CT (52\%: 0-10 cm; 50\%: $10-20 \mathrm{~cm} ; 67 \%: 20-30 \mathrm{~cm})$. It is important to mention that $\mathrm{R}$ pores are less effective in transmitting water 


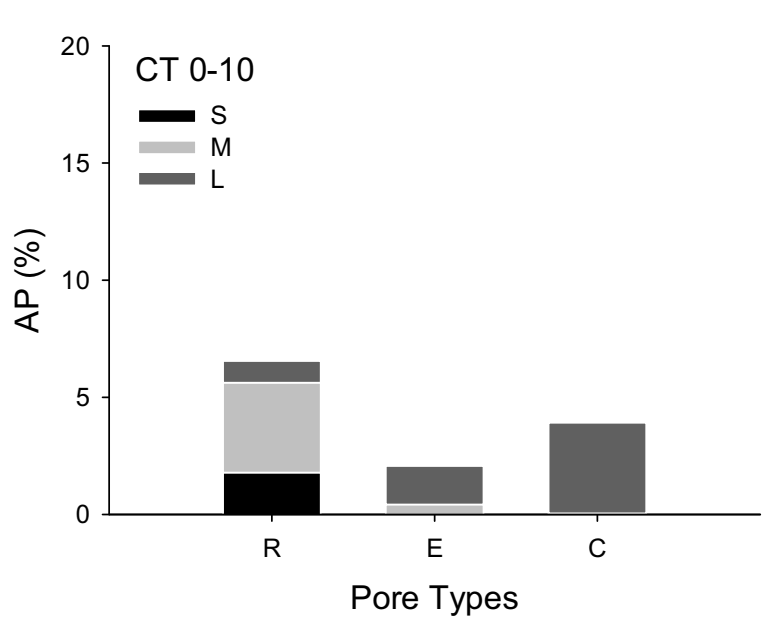

(a)

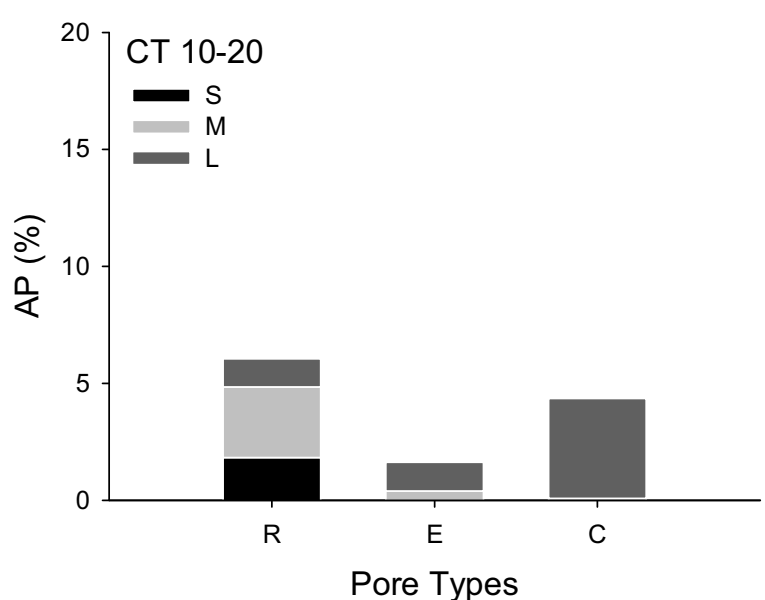

(c)

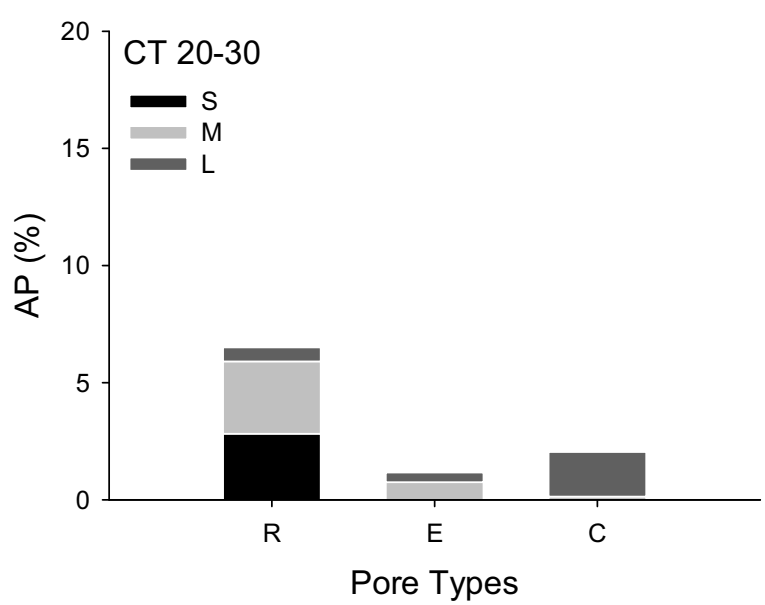

(e)

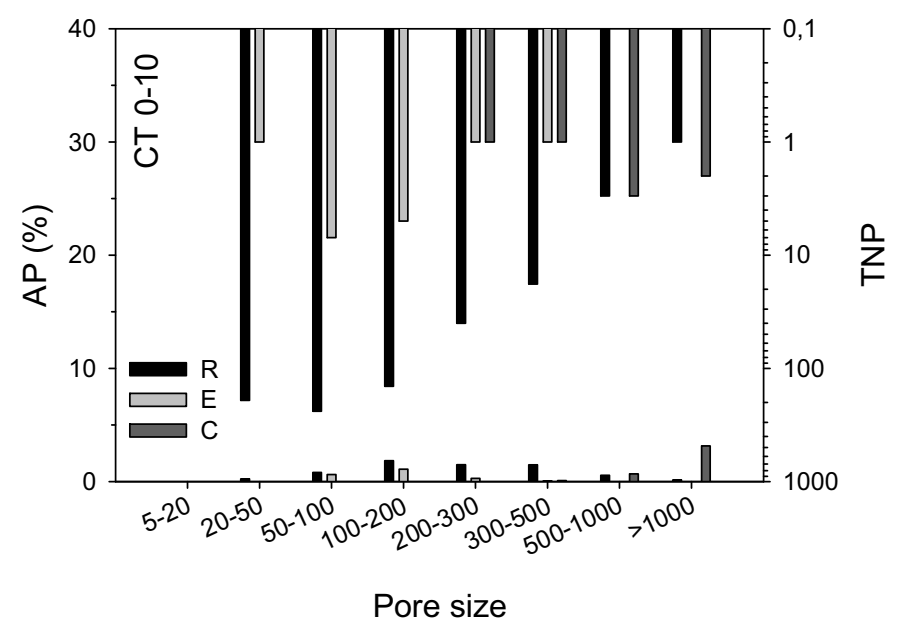

(b)

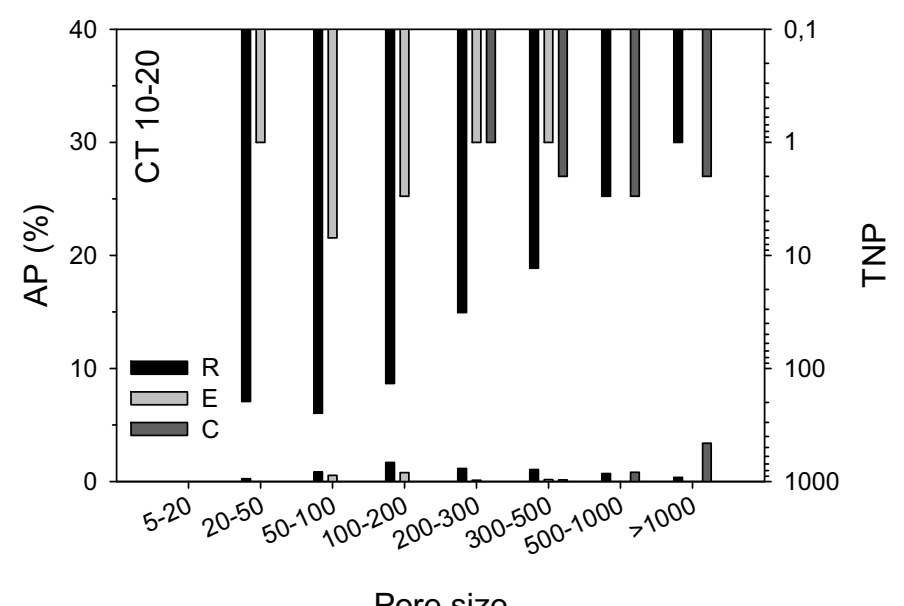

(d)

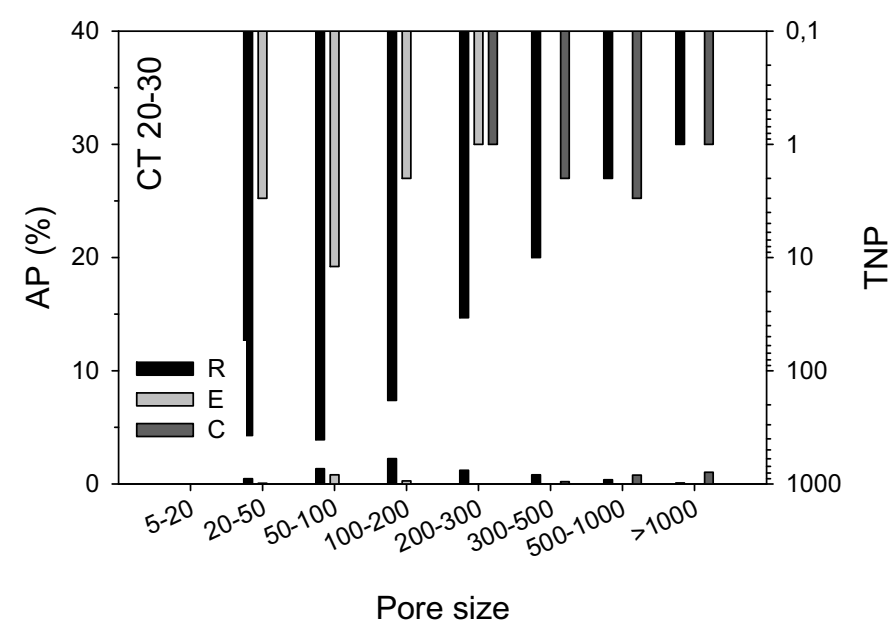

(f)

Fig. 3. Variations in the areal porosity (AP) and total number of pores (TNP) for the layers $0-10(a, b), 10-20$ (c, d) and 20-30 cm (e, f) for the soil under conventional tillage (CT) system. S: small; M: medium; L: large; R: rounded; E: elongated; C: complex. Pores size (ECD) in $\mu \mathrm{m}$. 


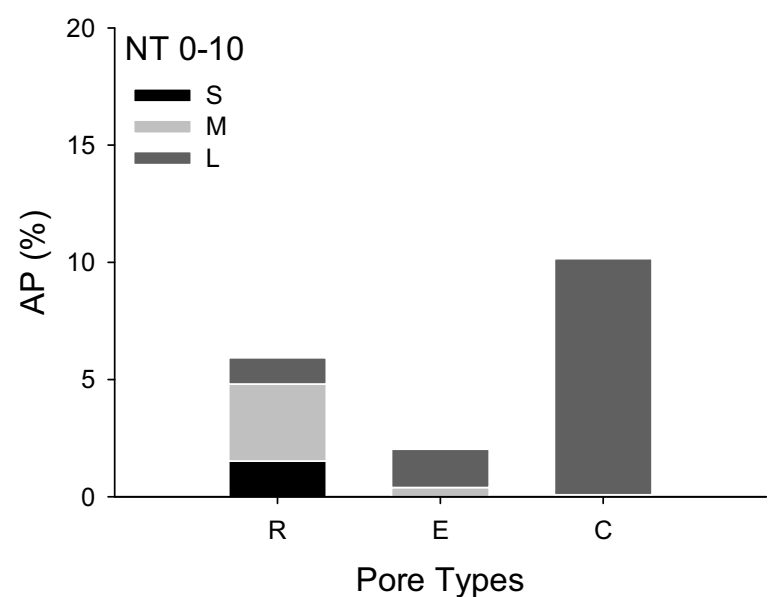

(a)

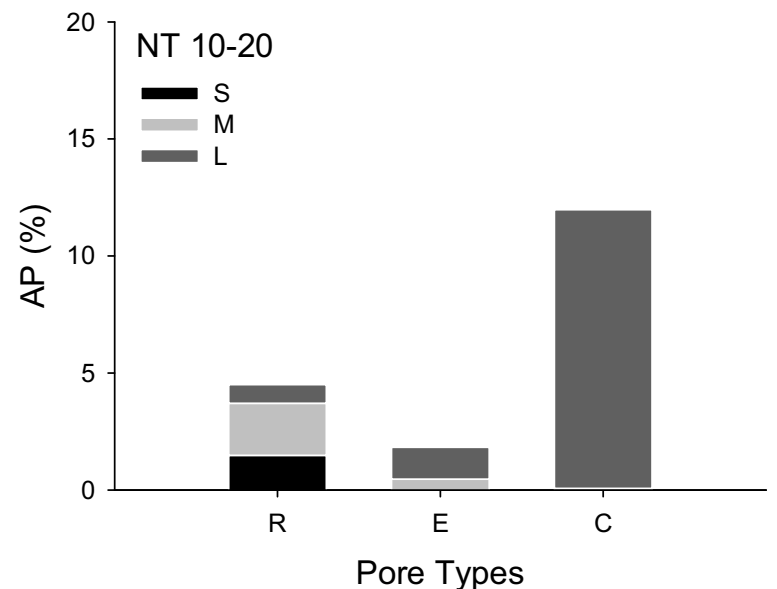

(c)

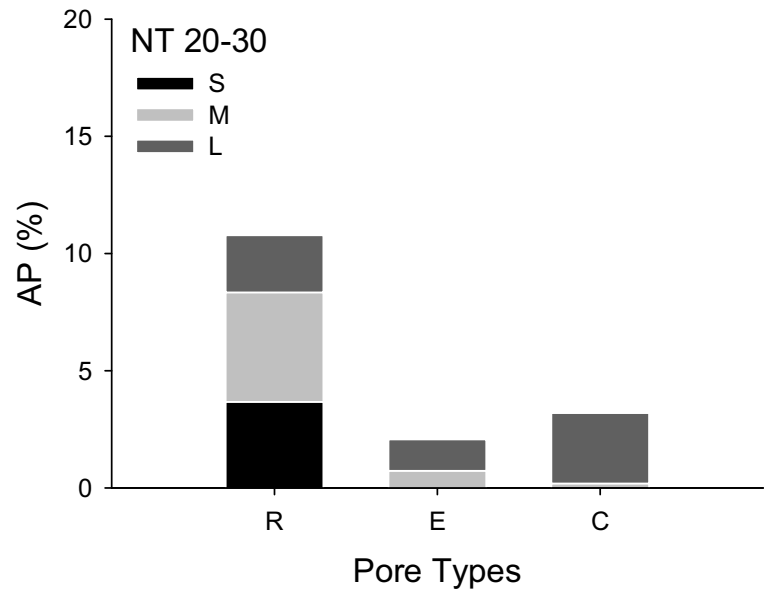

(e)

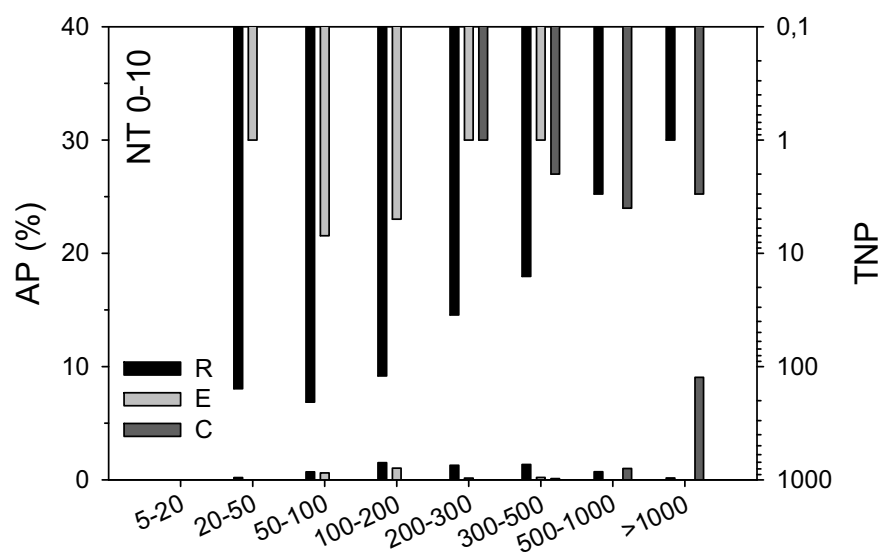

Pore size

(b)

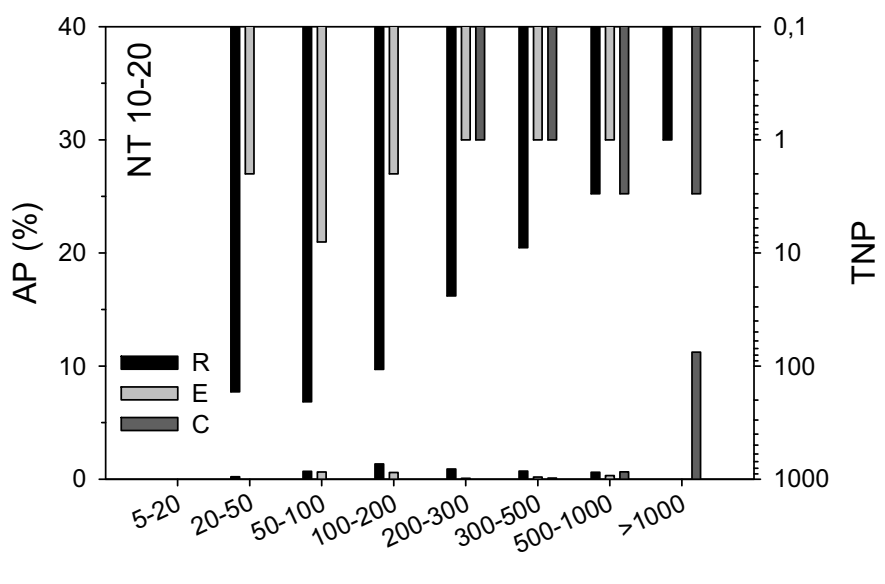

Pore size

(d)

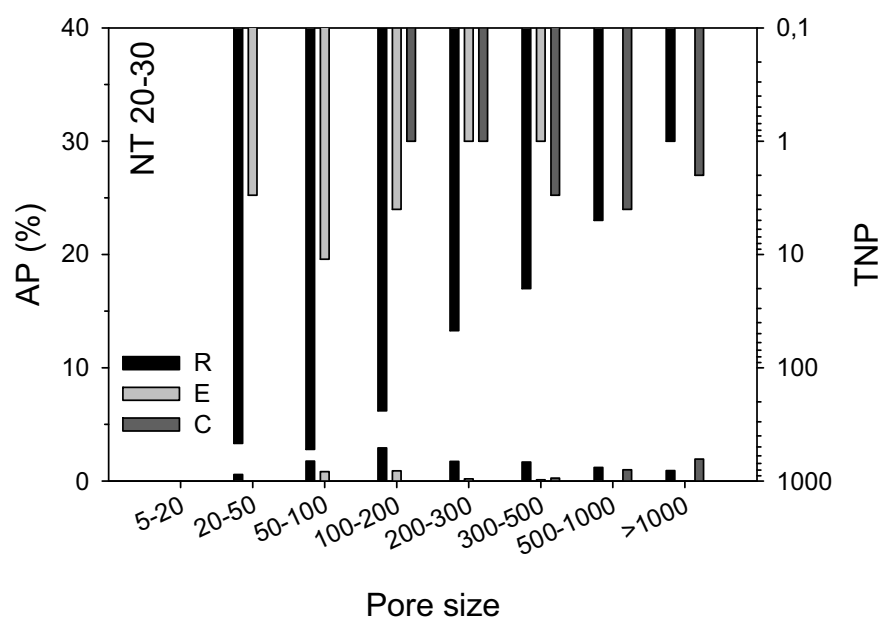

(f)

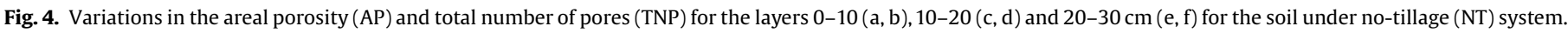
S: small; M: medium; L: large; R: rounded; E: elongated; C: complex. Pores size (ECD) in $\mu \mathrm{m}$. 
Table 3

Areal porosity (AP) and total number of pores (TNP).

\begin{tabular}{llllllll}
\hline Property & CT & \multicolumn{7}{l}{} & & & NT \\
\cline { 2 - 3 } \cline { 7 - 8 } & $0-10$ & $10-20$ & $20-30$ & & $0-10$ & $10-20$ & $20-30$ \\
\hline AP (\%) & 12.5 & 12.0 & 9.7 & & 18.1 & 18.3 & 16.0 \\
TNP & 659 & 651 & 1035 & & 561 & 540 & 1332 \\
\hline
\end{tabular}

CT: conventional tillage; NT: no-tillage.

than the other pore types (Fox et al., 2004; Pagliai et al., 2004). However, it is also important to analyze the PSD and the TNP distribution.

According to the classification proposed by Greenland and Pereira (1977), the soil pores can be divided into four different groups. Pores $<0.005 \mu \mathrm{m}$ in ECD are classified as bonding pores and their function is to support major forces between soil particles; those between $0.5-0.005 \mu \mathrm{m}$ are residual pores responsible for the retention and diffusion of ions in solutions; those between 50 $0.5 \mu \mathrm{m}$ are storage pores, which control water retention to the plants and microorganisms; and $>50 \mu \mathrm{m}$ are transmission pores related to the air movement and drainage of excess water (Lal and Shukla, 2004). The last group is important for the penetration and growth of the roots. Pores $>500 \mu \mathrm{m}$ are also known as fissures, and they might play an important role on root penetration and water movement, particularly in finer textured soils (Pagliai et al., 2004).

Taking into consideration the classification proposed by Greenland and Pereira (1977), for the description of pore distribution in the soil studied, it is possible to say that for the upper layer $(0-10 \mathrm{~cm})$ about $36 \%$ of the AP belonged to pores $>500$ $\mu \mathrm{m}, 62 \%$ to pores between 50 and $500 \mu \mathrm{m}$ and $2 \%$ to pores $<50 \mu \mathrm{m}$ (Fig. 3b). Regarding the intermediate $(10-20 \mathrm{~cm})$ and the lower layer $(20-30 \mathrm{~cm})$, the following contributions to AP were found: $44 \%(>500 \mu \mathrm{m}), 54 \%(50-500 \mu \mathrm{m})$ and $2 \%(<50 \mu \mathrm{m})$, and $24 \%(>500 \mu \mathrm{m}), 71 \%(50-500 \mu \mathrm{m})$ and $5 \%(<50 \mu \mathrm{m})$, respectively

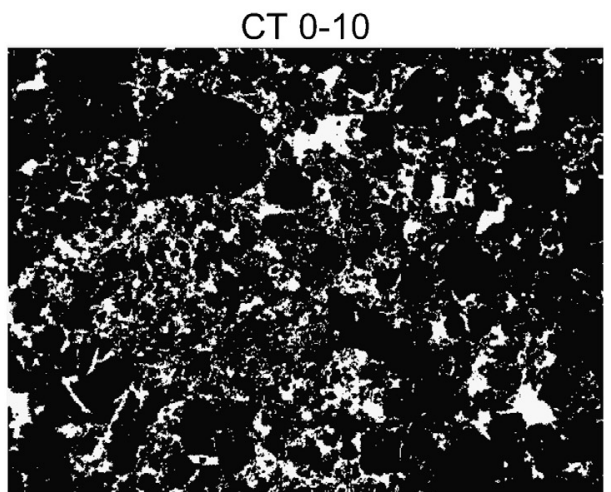

(a)

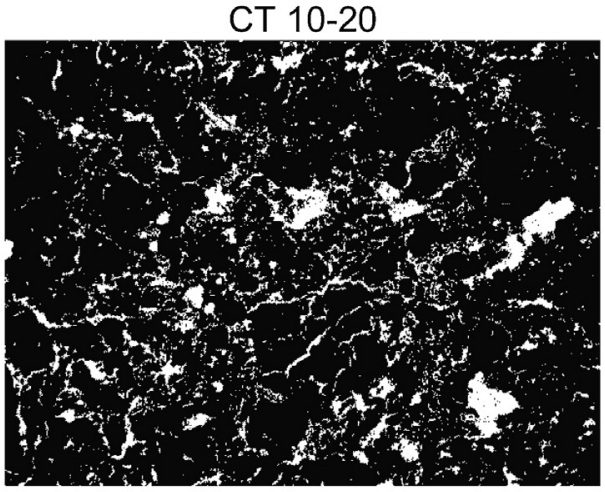

(c)

CT $20-30$

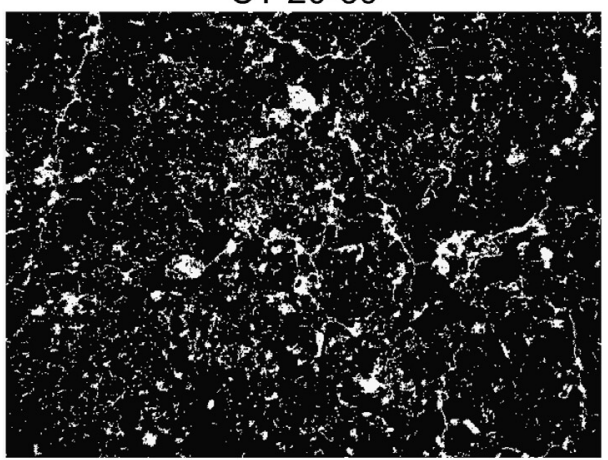

(e)

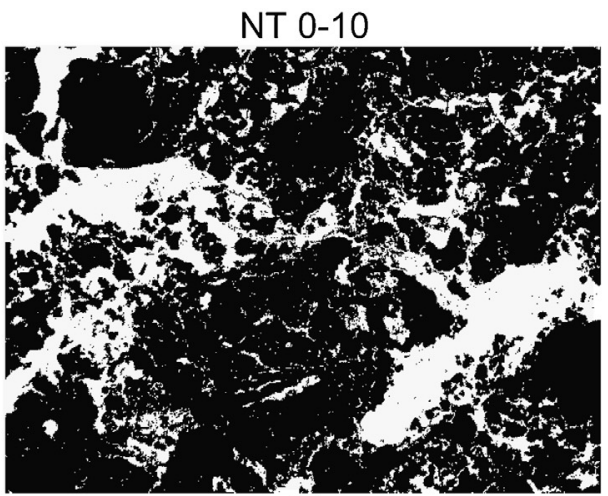

(b)

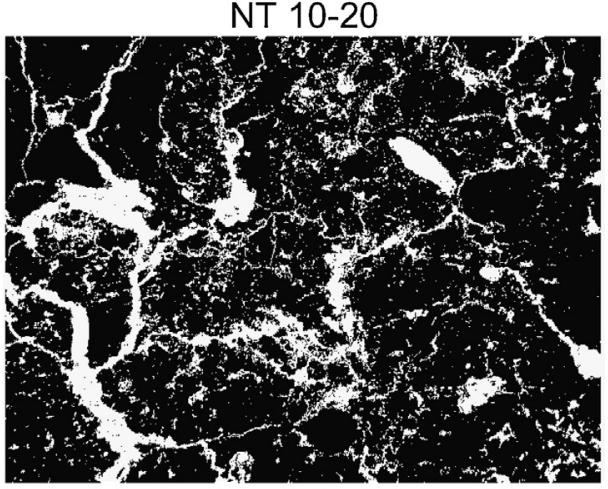

(d)

NT 20-30

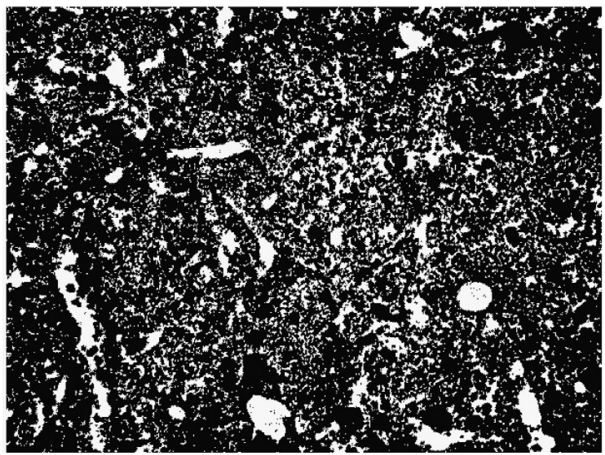

(f)

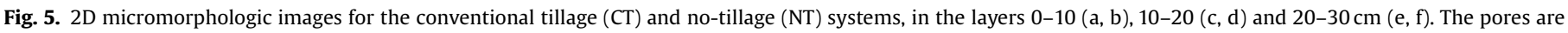
presented in white. 
(Figs. 3d,f). It is important to mention that the 2D image analysis only allowed the identification of pores with sizes larger than $20 \mu \mathrm{m}$.

Although the large contribution to AP is due to R pores (Figs. 3a, c,e), it was possible to observe through the PSD that the largest contribution to its value belonged to the transmission pore class (Figs. 3b,d,f). This result is really interesting in terms of water infiltration and distribution (Lipiec et al., 2006; Pagliai et al., 2004). $R$ pores made up a larger contribution to AP in the disturbed layers, due to the breakage of other types of pores into R pores (Fox et al., 2004).

In relation to TNP, for the upper layer $(0-10 \mathrm{~cm})$ around $2 \%$ of TNP were classified as fissures $(>500 \mu \mathrm{m}), 69 \%$ as transmission pores $(50-500 \mu \mathrm{m})$ and $29 \%$ as storage pores $(<50 \mu \mathrm{m})$ (Fig. $3 \mathrm{~b})$. For the intermediate $(10-20 \mathrm{~cm})$ and the lower layers $(20-30 \mathrm{~cm})$, around $2 \%$ and $1 \%$ of TNP were classified as fissures $(>500 \mu \mathrm{m}), 68 \%$ and $63 \%$ as transmission pores $(50-500 \mu \mathrm{m})$ and $30 \%$ and $36 \%$ as storage pores $(<50 \mu \mathrm{m})$, respectively (Figs. 3d,f). This result revealed the existence of big macropores, because a small number of pores exhibits a great contribution to AP for big pores $(>500 \mu \mathrm{m})$ (Fig. 5a,c,e).

Concerning the NT system, the difference in the AP between the upper and lower layers was $11 \%$ (Table 3 ). As observed for the CT system, the reduction in the AP with depth was not followed by TNP. Large $C$ pores presented a marked decrease with depth, which was an indication of a great pore connection for the surface layers of the soil under NT (Fig. 4a,c,e). As the soil investigated under NT was under permanent vegetation this result was expected due to the action of roots and organic matter (Tavares Filho and Tessier, 2009; Udawatta et al., 2006). The C and E pore types result from the aggregate assembly or elementary particles and pores of different types interconnected, which form a network with a large size and distinct delineated shapes (Bouma et al., 1977; Pagliai et al., 1984) (Fig. 5b,d,f).

The reduction in the contribution of $C$ pores to AP with depth was accompanied by an increase of the importance of $R$ pores (Fig. 4a,c,e). Contrary to the results observed for CT, the soil under NT system had the largest contribution to AP, for the upper (0$10 \mathrm{~cm}$ ) and intermediate $(10-20 \mathrm{~cm})$ layers, due to the large $C$ pore types. This contribution was $56 \%(0-10 \mathrm{~cm})$ and $65 \%(10-20 \mathrm{~cm})$ between the surface layers, respectively. On the other hand, the $R$ pore types presented a contribution to AP for the lower layer (20$30 \mathrm{~cm}$ ) of $67 \%$. This result was mainly related to the large amount of organic matter and presence of roots in the surface layers (Ogunwole et al., 2015).

Taking into consideration the classification proposed by Greenland and Pereira (1977), for the description of the distribution of pores for NT, it is possible to say that for the upper layer ( 0 $10 \mathrm{~cm}$ ) about $60 \%$ of the AP belonged to pores $>500 \mu \mathrm{m}, 39 \%$ to pores between 50 and $500 \mu \mathrm{m}$ and $1 \%$ to pores $<50 \mu \mathrm{m}$ (Fig. $4 \mathrm{~b}$ ). Regarding the intermediate $(10-20 \mathrm{~cm})$ and the lower layer $(20-$ $30 \mathrm{~cm})$, the following contributions to AP found were: $70 \%$ $(>500 \mu \mathrm{m}), 29 \%(50-500 \mu \mathrm{m})$ and $1 \%(<50 \mu \mathrm{m})$, and $31 \%$ $(>500 \mu \mathrm{m}), 65 \%(50-500 \mu \mathrm{m})$ and $4 \%(<50 \mu \mathrm{m})$, respectively (Figs. 4d, f).

In relation to TNP, for the upper layer $(0-10 \mathrm{~cm})$ around $2 \%$ of TNP were classified as fissures $(>500 \mu \mathrm{m}), 70 \%$ as transmission

Table 4

Macroporosity (MAP) and number of macropores (NMAP) for the conventional tillage (CT) and no-tillage (NT) systems.

\begin{tabular}{|c|c|c|c|c|c|c|}
\hline \multirow[t]{2}{*}{ Property } & \multicolumn{3}{|l|}{$\mathrm{CT}$} & \multicolumn{3}{|l|}{ NT } \\
\hline & $0-10$ & $10-20$ & $20-30$ & $\overline{0-10}$ & $10-20$ & $20-30$ \\
\hline MAP (\%) & 10.4 & 12.4 & 7.3 & 10.8 & 7.4 & 7.2 \\
\hline NMAP & 30,530 & 32,040 & 40,547 & 21,592 & 29,608 & 19,047 \\
\hline
\end{tabular}

pores $(50-500 \mu \mathrm{m})$ and $28 \%$ as storage pores ( $<50 \mu \mathrm{m})$ (Fig. $4 \mathrm{~b})$. For the intermediate $(10-20 \mathrm{~cm})$ and the lower layer $(20-30 \mathrm{~cm})$, around $2 \%$ and $1 \%$ of TNP were classified as fissures $(>500 \mu \mathrm{m}), 67 \%$ and $64 \%$ as transmission pores $(50-500 \mu \mathrm{m})$ and $31 \%$ and $35 \%$ as storage pores $(<50 \mu \mathrm{m})$, respectively (Figs. $4 \mathrm{~d}, \mathrm{f}$ ).

\subsection{Micromorphological analysis ( $\mu C T)$}

MAP and NMAP results for CT and NT tillage systems are presented in Table 4 . For CT, the smallest MAP for $0-10 \mathrm{~cm}$ layer, in relation to $10-20 \mathrm{~cm}$, can be associated with soil reorganization after disk plowing; climate action (rainfall, root system growth, etc) and agricultural machinery traffic. Once in 3D segmented image each pore is defined as a void voxel surrounded by solid voxels, the occurrence of the smallest MAP and highest NMAP for $20-30 \mathrm{~cm}$ was an evidence of the existence of many unconnected pores.

For NT, MAP decreased with depth. However, 10-20 and 20$30 \mathrm{~cm}$ layers presented similar values ( $D R=2.70 \%$ ). Regarding NMAP, maximum and minimum values were respectively observed for $10-20$ and $20-30 \mathrm{~cm}$. In general, results showed that $20-30 \mathrm{~cm}$ layer have the lowest MAP and the highest NMAP (Table 4). However, regularities between these two physical attributes were not observed for any other layer.

From these results, it is possible to conclude that MAP and NMAP analyses, by means of 3D $\mu \mathrm{CT}$ images for CT and NT tillage systems, showed no evidence of regularities, that is, MAP was not conditioned by NMAP for the analyzed samples. This conclusion is justified because the study of MAP via $\mu \mathrm{CT}$ is directly related to the total volume of pores within the soil image, but not to their amount (Eq. (3)).

When comparing MAP results for both tillage systems, the similarities for $0-10$ and $20-30 \mathrm{~cm}$ became evident ( $\mathrm{DR}=3.85 \%$ and $\mathrm{DR}=1.37 \%$, respectively). However, for all analyzed layers, NMAP was higher for CT in comparison to NT. The aforementioned result can be associated to aggregate breakdown induced by disk plowing. In turn, regarding the $10-20 \mathrm{~cm}$ layer, the major difference between CT and NT (DR $=40.32 \%$ ) can be associated to "no-till pan" effect. Reports available in the literature showed that, in layers of about 7-15-20 cm, agricultural machinery traffic might induce a higher bulk density in these layers, which may hamper root growth (Reichert et al., 2009, 2007).

3D Images revealed relevant differences between the porous system of soils under CT and NT. For NT, branches were welldefined while for CT, MAP consisted of higher complexity agglomerated macropores. Moreover, large macropores $>1000 \mathrm{~mm}^{3}$ were present in all samples. Such type of macropores had several branches throughout the entire sample volume.

Such configurations of macropores were previously detected by Borges (2015); Jefferies (2014); Passoni et al. (2015); Quinton et al. (2009) and Rezanezhad et al. (2009). It is important to emphasize the relevance of large and well branching macropores in the soil, mainly when preferential flow was considered. Smaller and disconnected macropores provided more sinuous flow path and their contribution to flow may be neglected when a very large pore is active (Rezanezhad et al., 2009).

With the purpose of carefully examining pore size distribution, MAP and NMAP were plotted as a function of pore volume intervals (Fig. 6). There are one to two wide-branched-macropores per sample. These macropores had volume from about $69-5,663 \mathrm{~mm}^{3}$ and $47-5,227 \mathrm{~mm}^{3}$ for CT and NT samples, respectively. They are important to the MAP, however, the highest contribution for NMAP was given by the small pore sizes, which were detected in higher amount in the soil images.

For CT, the highest contribution to MAP given by macropores $>1000 \mathrm{~mm}^{3}$ occurred for $10-20 \mathrm{~cm}(91 \%$ ) (Fig. $6 \mathrm{c}$ ) and, the smallest, 


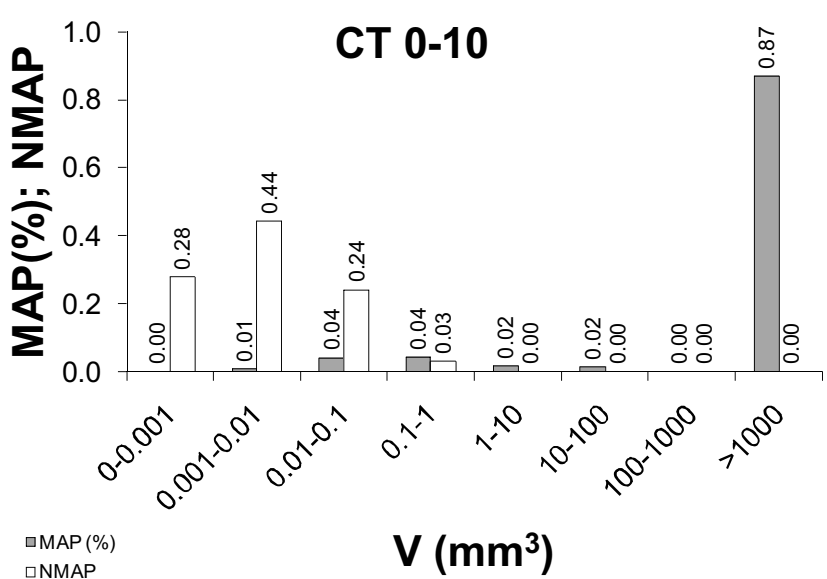

(a)

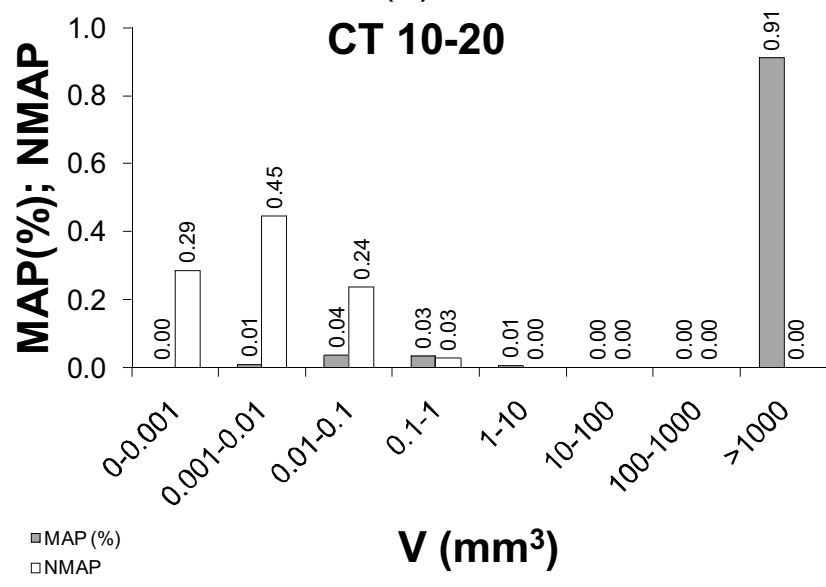

(c)

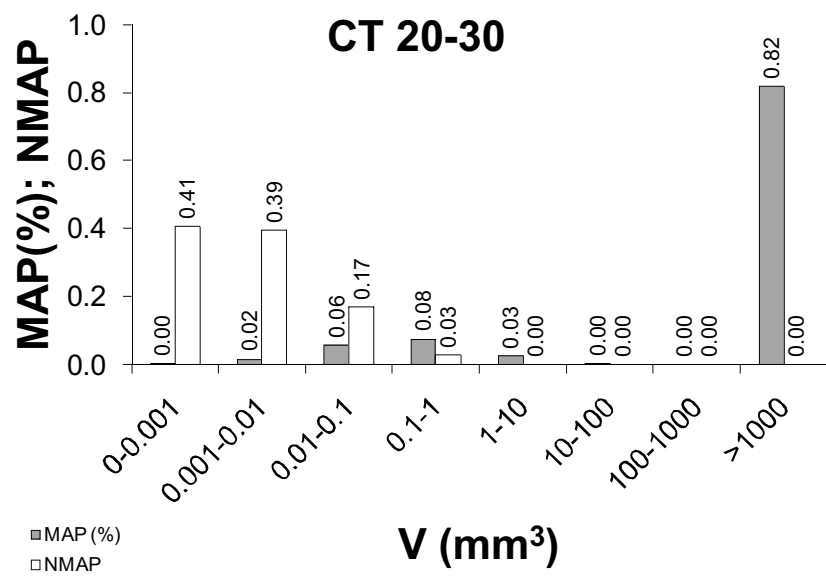

(e)

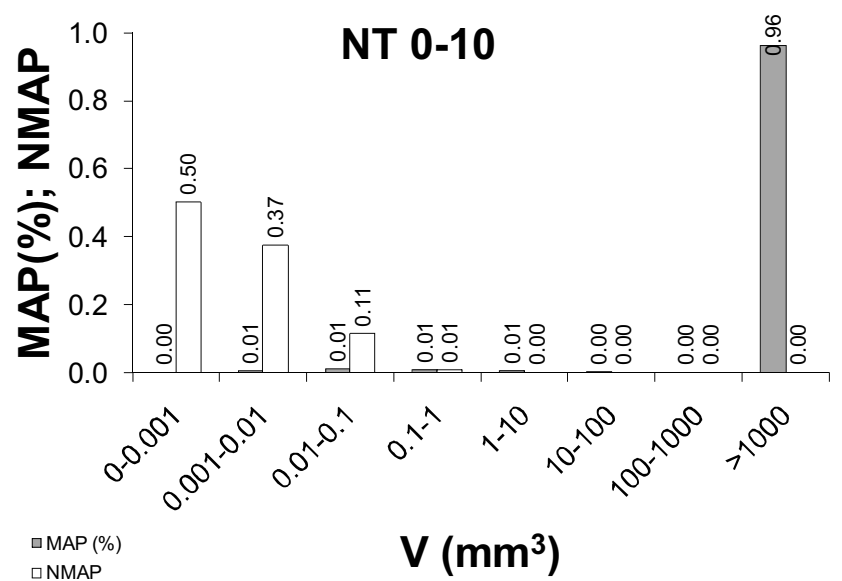

(b)

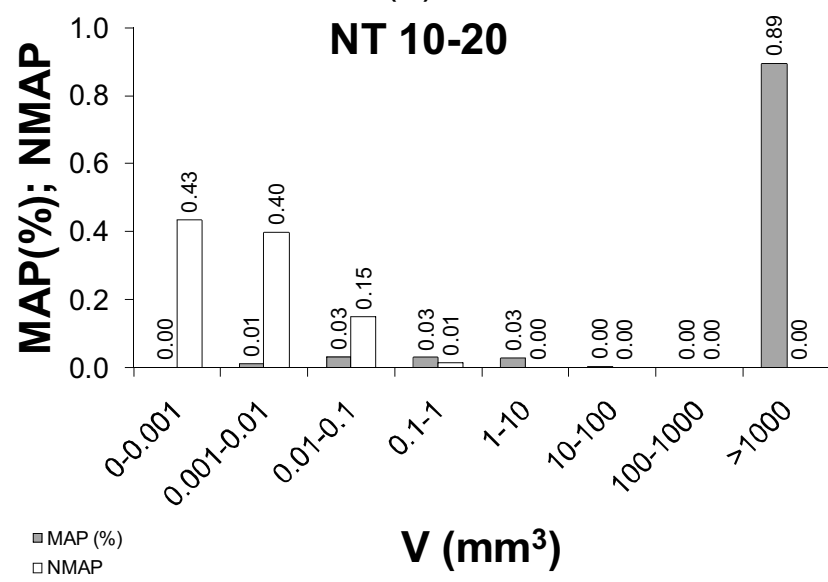

(d)

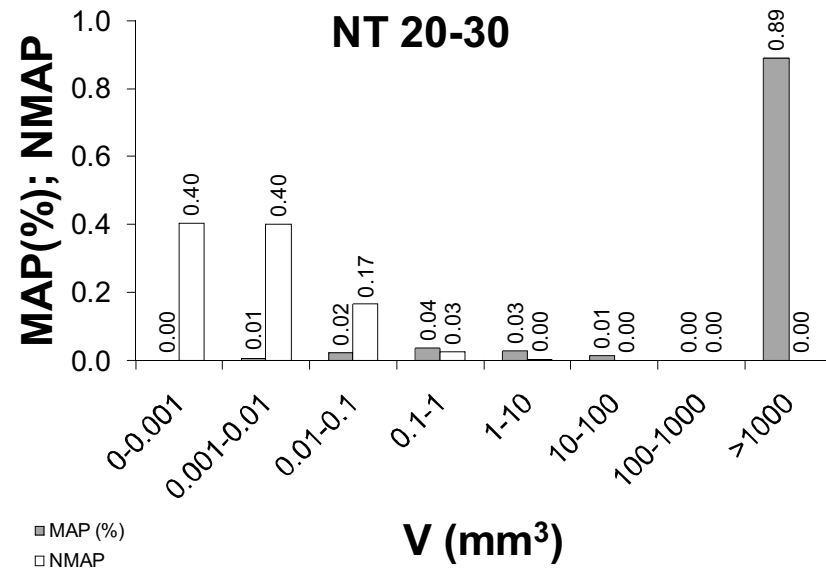

(f)

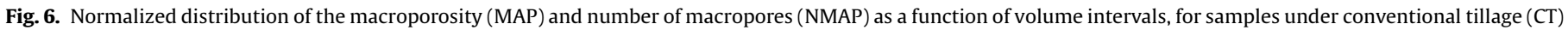
and no-tillage (NT) systems, in the layers 0-10 (a, b), 10-20 (c, d) and 20-30 cm (e, f).

for $20-30 \mathrm{~cm}$ (82\%) (Fig. 6e). This is an important result, since such macropores play an important role for hydraulic conductivity, aeration and development of root system (Hillel, 1998; Jury and Horton, 2004). Regarding NMAP, macropores of $0.1 \mathrm{~mm}^{3}$ gave the highest contributions. These macropores, despite abounding, were negligible when considering the MAP of the total sample volume.

Once the $20-30 \mathrm{~cm}$ layer had the highest NMAP for CT, it is important to notice the agreement between the following two results (Table 4 and Fig. 6e): smaller contribution of macropores $>1000 \mathrm{~mm}^{3}$ to MAP indicated considerable number of smaller macropores. Indeed, the highest NMAP was made of macropores $0-0.001 \mathrm{~mm}^{3}$. Besides that, when compared to the remaining layers, $20-30 \mathrm{~cm}$ had the highest NMAP for this volume interval.

For NT, MAP contribution of macropores $>1000 \mathrm{~mm}^{3}$ was $96 \%$ for $0-10 \mathrm{~cm}$, and $89 \%$ for $10-20$ and $20-30 \mathrm{~cm}$ (Fig. $6 \mathrm{~b}, \mathrm{~d}, \mathrm{f}$ ). Regarding NMAP, there was a decrease with soil depth in 


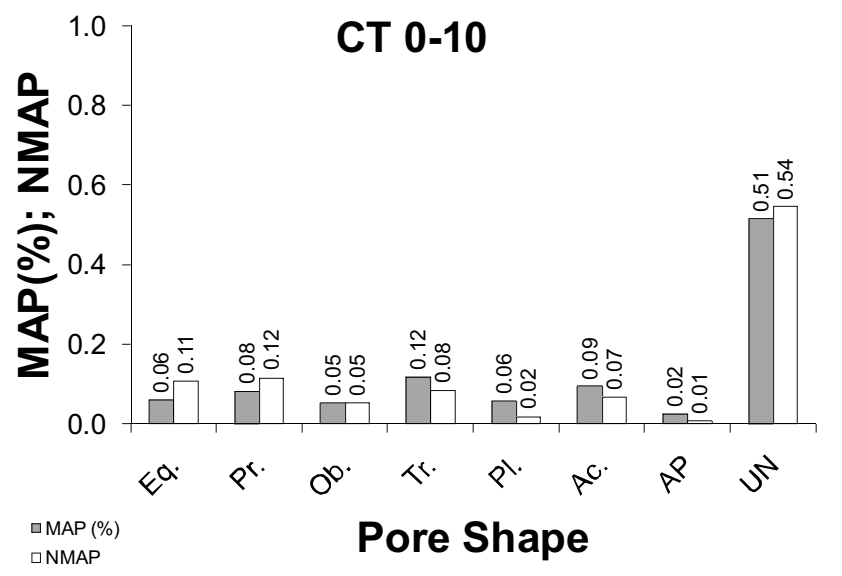

(a)

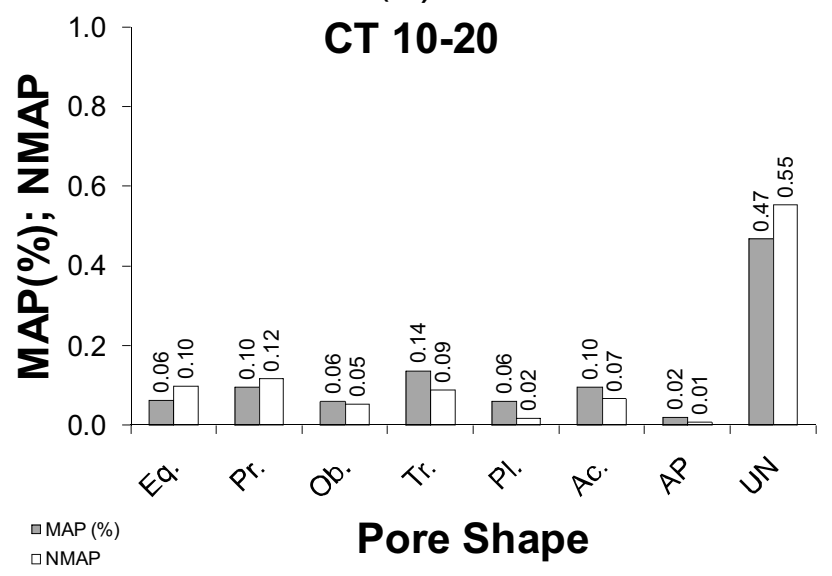

(c)

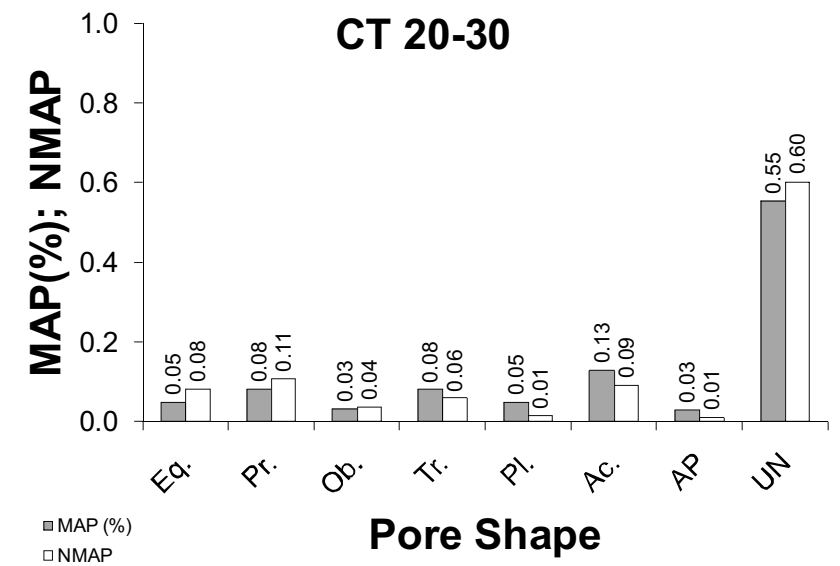

(e)

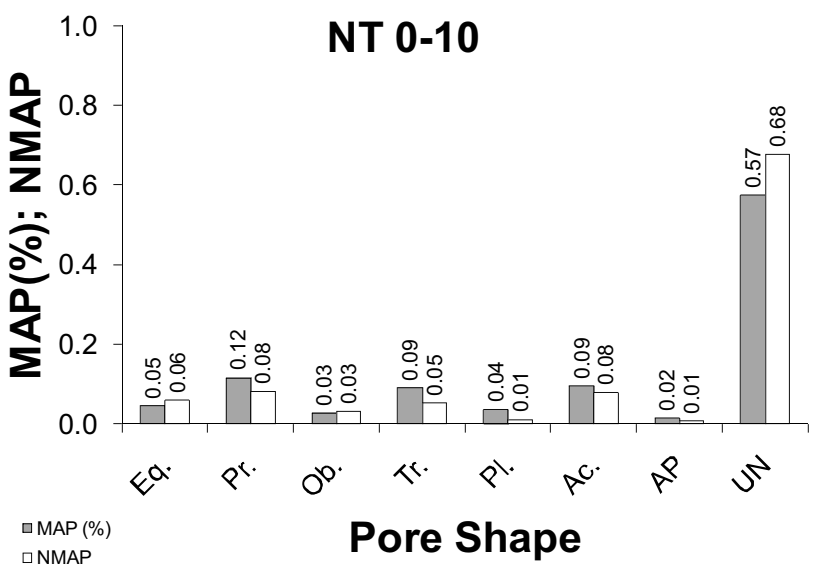

(b)

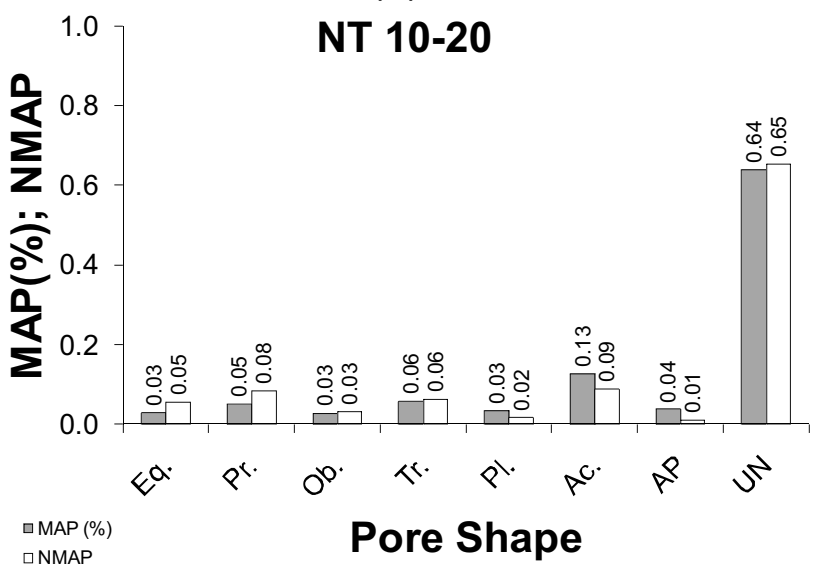

(d)

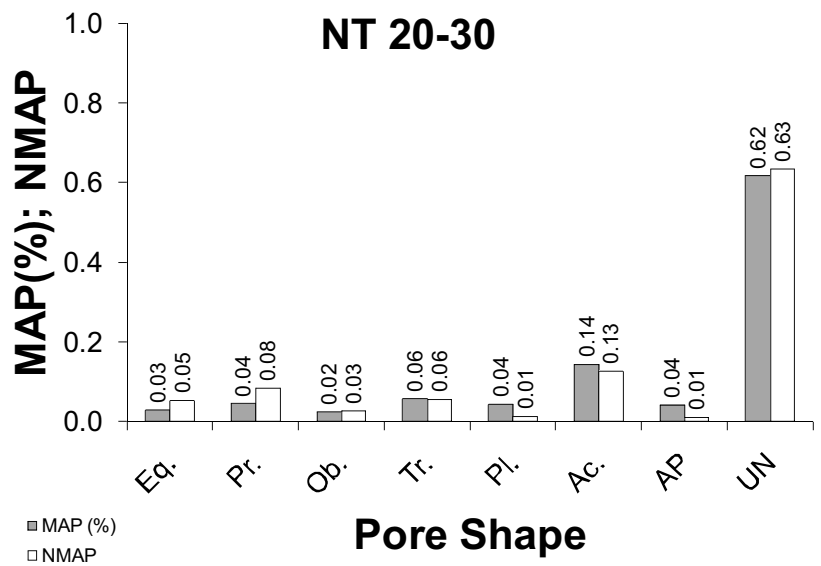

(f)

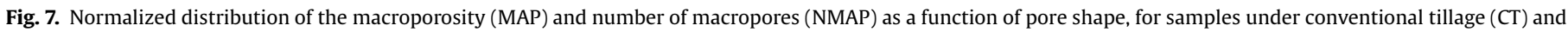
no-tillage (NT) systems, in the layers 0-10 (a, b), 10-20 (c, d) and 20-30 cm (e, f).

macropores $0-0.001 \mathrm{~mm}^{3}$, and an increase of macropores $0.01-$ $0.1 \mathrm{~mm}^{3}$. However, the number of macropores $0.001-0.01 \mathrm{~mm}^{3}$ was higher for $0-10 \mathrm{~cm}$ (37\% of NMAP) and remained the same for $10-20$ and $20-30 \mathrm{~cm}$ (40\%). Comparing the two tillage systems, the MAP contribution given by macropores $>1000 \mathrm{~mm}^{3}$ was higher for $0-10$ e $20-30 \mathrm{~cm}$ of NT.

Regarding pore shape (Fig. 7), for NT it was possible to classify $32 \%$ of $0-10 \mathrm{~cm}$ for NMAP, $35 \%$ for $10-20 \mathrm{~cm}$ and $37 \%$ for $20-30 \mathrm{~cm}$ (Fig. 7b,d,f). These results indicated a well-defined pore shape with depth for NT, once the percentage of classified pores increased gradually.

For all analyzed layers, the classified NMAP was higher for CT when comparing to NT: $46(0-10 \mathrm{~cm}), 45(10-20 \mathrm{~cm})$ and $40 \%(20-$ $30 \mathrm{~cm}$ ) (Fig. 7a,c,e). This indicated some uniformity in pore shapes for soil under $\mathrm{CT}$, which can be associated to the disk plowing process. Besides that, the decrease in the number of unclassified macropores as a function of soil depth indicated a more complex pore shape in the soil deeper layers. 
The most abundant pore shape in the CT samples was Eq., Pr., Tr. and Ac. (5-13\% of NMAP). For NT, the percentage of NMAP of each pore shape was similar for the three analyzed layers, except for Ac. shape, which had a more evident increase in the $20-30 \mathrm{~cm}$ layer. In turn, there was a decrease in Eq. macropores for CT with depth.

The occurrence of several pore shapes is related to the soil type, as well as to the applied treatments. In particular, the presence of Pr. pores may indicate the soil quality, once they might be related to biological and root activity (biopores) (Carducci et al., 2014; Genro Junior et al., 2004; Lima et al., 2005).

The complexity of the shape justified the high amount of unclassified macropores observed for both tillage systems. Specifically, the greater complexity of macropores shape in the $0-10 \mathrm{~cm}$ layer for NT (the highest unclassified NMAP) could be associated to factors as root growth, wetting-drying cycles, biotic and human actions, which are more intense in the soil surface layer (Alvarez and Steinbach, 2009; Cássaro et al., 2011; Fox et al., 2004; Hajnos et al., 2006; Hussain et al., 1998).

Similarly to the number of unclassified macropores for CT, the macropore tortuosity increased with soil depth (Table 5 and Fig. 7a, $c, e)$. The agreement of these two attributes showed that, the deeper they are, the more irregular are the pores shape for soil under CT. For NT, only $20-30 \mathrm{~cm}$ layer showed relation between these two attributes (smaller $\tau$ and unclassified NMAP when comparing to the other layers). However, it is noteworthy that there was low variability among the number of classified macropores for all the layers of NT (Fig. 7b,d,f).

Regarding connectivity, this was higher for $10-20 \mathrm{~cm}$ for CT (smaller EPC values). Such result is in accordance to the higher contribution of macropores $>1000 \mathrm{~mm}^{3}$ to MAP (Fig. 6c). Besides that, it was possible to observe that connectivity became smaller with depth, which may be justified by the disk plow depth up to about $25 \mathrm{~cm}$. For NT, better connectivity occurred for $0-10 \mathrm{~cm}$, which presented smaller EPC values. This result is in agreement with the higher contribution of macropores $>1000 \mathrm{~mm}^{3}$ to MAP. In turn, the intermediate layer $(10-20 \mathrm{~cm})$ presented small connectivity among NT layers $(\mathrm{EPC}=71.35)$.

\section{Concluding remarks}

This study has enabled the evaluation of the modifications induced by CT and NT in the soil structure. Besides that, employment of different tools allowed the examination of several physical attributes in 2D and 3D, at different scales.

The soil water retention adjustment through a cubic spline function allowed the identification of the textural and structural domain of the soil under different tillage systems. Tri-modal and bi-modal PSDs were found for CT and NT. The separation between the textural and structural domains for CT was similar among layers. Similar results were observed for the soil under NT.

Comparing the tillage systems, larger values of $\varphi$ were observed for NT in relation to CT for all the depths analyzed, which is an indication of the damages caused in the soil structure by the soil disturbance under CT mainly for the upper layer $(20-30 \mathrm{~cm})$. PSDs

Table 5

Tortuosity $(\tau)$ and Euler-Poincaré characteristic (EPC) for the conventional tillage (CT) and no-tillage (NT) systems, in the layers $0-10,10-20$ and $20-30 \mathrm{~cm}$.

\begin{tabular}{llllllll}
\hline Property & $\mathrm{CT}$ & \multicolumn{7}{l}{$\mathrm{NT}$} \\
\cline { 2 - 3 } \cline { 7 - 8 } \cline { 7 - 8 } & $0-10$ & $10-20$ & $20-30$ & & $0-10$ & $10-20$ & $20-30$ \\
\hline$\tau$ & 1.49 & 1.63 & 1.77 & & 1.53 & 1.70 & 1.47 \\
EPC & -12.87 & -45.74 & 109.11 & & 11.23 & 71.35 & 35.74 \\
\hline
\end{tabular}

also presented differences between tillage methods, mainly in the region of the structural domain related to big pore sizes (Tuzzin de Moraes et al., 2016). The differences were more pronounced for CT than NT.

In the textural domain, the effects of the tillage systems in the soil structure were practically the same. Usually, the small pores were less affected by changes induced in the soil by the machinery operations (Hillel, 1998). The presence of channels and biopores promoted by the action of worms, dead roots and soil fauna could help to explain the differences in the structural domain between CT and NT (Lal and Shukla, 2004; Tavares Filho and Tessier, 2009; Zaffar and Lu, 2015).

From the 2D micromorphological analysis, as shown by the resin-impregnated blocks, it was possible to evaluate the areal porosity and the total number of pores. For the soil submitted to both tillage systems a decrease in AP with soil depth was observed. However, this decrease was not followed by a decrease in TNP. The 2D soil images indicated important differences in the soil porous system between CT and NT. Lower layers presented similar structures between them. This is an indication that for depths $>20$ to $25 \mathrm{~cm}$ the soil under CT and NT systems start to present similar structures (Cássaro et al., 2011). The same result was observed regarding TNP, with the increase in the number of pores with depth. The increase in TNP for both systems occurred mainly for small and medium size R pores.

However, the great contribution of large $C$ pores to AP for the soil under NT in comparison to CT was an indication of the presence of a large amount of fissures and biopores for NT. This result indicated a more complex structure for the soil under NT, which can favor water infiltration positively reducing environmental problems such as soil erosion. As previously described, the largest amount of big pores present in the samples under NT on the surface was caused by the more intense fauna activity with a larger predominance of channels owing to the crop roots (Hussain et al., 1998).

From 3D $\mu \mathrm{CT}$ images, it was possible to carry out qualitative and quantitative studies of soil macropores. From the 3D images, it was possible to visualize branches with a better definition for NT. In turn, MAP, NMAP, pore shape and distributions, tortuosity and connectivity could be evaluated from quantitative analyses. To sum up, the key conclusions from $\mu \mathrm{CT}$ analyses were: (1) MAP was not conditioned by NMAP; (2) MAP was similar to $0-10$ and $20-30 \mathrm{~cm}$ in both tillage systems; (3) for all analyzed layers, NMAP was higher for CT in comparison to NT; (4) results of number of unclassified macropores and tortuosity for CT showed more irregular pore shape with depth for CT and (5) better connectivity was found for $0-10$ and $10-20 \mathrm{~cm}$ in CT.

In general, such analyses indicate higher agreement among results of different attributes in $\mathrm{CT}$, when comparing to NT. These results are associated to the structure homogenization of soil under CT, induced by disk plowing (Marcolan and Anghinoni, 2006).

\section{Acknowledgments}

The authors acknowledge CNPq ("Conselho Nacional de Desenvolvimento Científico e Tecnológico") for the provision of the productivity grant in research (303726/2015-6) to Dr. Luiz F. Pires; To CNEN ("Comissão Nacional de Energia Nuclear") and CAPES ("Coordenação de Aperfeiçoamento de Pessoal de Nível Superior") for the PhD and Sandwich PhD scholarships (BEX 1771/ 14-0) to Jaqueline A.R. Borges and to CNEN for the Master scholarship for Sabrina Passoni. 


\section{References}

Allaire-Leung, S., Gupta, S., Moncrief, J., 2000. Water and solute movement in soil as influenced by macropore characteristics. J. Contam. Hydrol. 41, 283-301. doi: http://dx.doi.org/10.1016/S0169-7722(99)00079-0.

Alvarez, R., Steinbach, H.S., 2009. A review of the effects of tillage systems on some soil physical properties, water content, nitrate availability and crops yield in the Argentine Pampas. Soil Tillage Res. 104, 1-15. doi:http://dx.doi.org/10.1016/j. still.2009.02.005

Amer, A.-M.M., Logsdon, S.D., Davis, D., 2009. Prediction of hydraulic conductivity as related to pore size distribution in unsaturated soils. Soil Sci. 174, 508-515. doi: http://dx.doi.org/10.1097/SS.0b013e3181b76c29.

Anderson, S.H., Udawatta, R.P., Kumar, S., Gantzer, C.J., Rachman, A., 2010. CTmeasured macropore parameters for estimating saturated hydraulic conductivity at four study sites. 19th World Congress of Soil Science, Soil Solutions for a Changing World, Published on DVD, Brisbane, pp. 13-16.

Arcaro, K., 2013. Caracterização geométrica e topológica da competência mecânica no estudo da estrutura trabecular (Geometric and Topological Characterization of the Mechanical Competence in the Study of the Trabecular Structure). Doctoral Thesis. Federal University of Rio Grande do Sul, Rio Grande do Sul, pp. 84 in Portuguese, with English abstract.

Borges, J.A.R., 2015. Tamanhos elementares representativos de atributos do solo via atenuação de raios gama e tomografia computadorizada (Representative Elementary Sizes of Soil Physical Properties via Gamma Ray Attenuation and Computed Tomography). Doctoral Thesis. State University of Ponta Grossa, Ponta Grossa, pp. 119 in Portuguese, with English abstract.

Bouma, J., Jongerius, A., Boersma, O., Jager, A., Schoonderbeek, D., 1977. The function of different types of macropores during saturated flow through four swelling soil horizons. Soil Sci. Soc. Am. J. 41, 945-950. doi:http://dx.doi.org/10.2136/ sssaj1977.03615995004100050028x.

Brown, K., Schlüter, S., Sheppard, A., Wildenschild, D., 2014. On the challenges of measuring interfacial characteristics of three-phase fluid flow with X-ray microtomography. J. Microsc. 253, 171-182. doi:http://dx.doi.org/10.1111/ jmi.12106.

Bullock, N.P., Fedoroff, A., Jongerius, A., Stoops, G., Tursina, T., 1985. Handbook for Soil Thin Section Description, 1st ed. Waine Research, England.

Buzug, T.M., 2008. Computed Tomography: From Photon Statistics to Modern ConeBeam CT. Springer, New York.

Cássaro, F.A.M., Borkowski, A.K., Pires, L.F., Rosa, J.A., Saab, S., da, C., 2011. Characterization of a Brazilian clayey soil submitted to conventional and notillage management practices using pore size distribution analysis. Soil Tillage Res. 111, 175-179. doi:http://dx.doi.org/10.1016/j.still.2010.10.004.

Carducci, C.E., César de Oliveira, G., Curi, N., Heck, R.J., Rossoni, D.F., 2014. Scaling of pores in 3D images of Latosols (Oxisols) with contrasting mineralogy under a conservation management system. Soil Res. 52, 231. doi:http://dx.doi.org/ 10.1071/SR13238.

Chappard, D., Legrand, E., Pascaretti, C., Baslé, M.F., Audran, M., 1999. Comparison of eight histomorphometric methods for measuring trabecular bone architecture by image analysis on histological sections. Microsc. Res. Tech. 45, 303-312. doi: http://dx.doi.org/10.1002/(SICI)1097-0029(19990515/01)45:4/5<303:AIDJEMT14>3.0.CO;2-8

Cooper, M., Vidal-Torrado, P., Chaplot, V., 2005. Origin of microaggregates in soils with ferralic horizons. Sci. Agric. 62, 256-263. doi:http://dx.doi.org/10.1590/ S0103-90162005000300009.

Dal Ferro, N., Delmas, P., Duwig, C., Simonetti, G., Morari, F., 2012. Coupling X-ray microtomography and mercury intrusion porosimetry to quantify aggregate structures of a cambisol under different fertilisation treatments. Soil Tillage Res. 119, 13-21. doi:http://dx.doi.org/10.1016/j.still.2011.12.001.

Dal Ferro, N., Sartori, L., Simonetti, G., Berti, A., Morari, F., 2014. Soil macro- and microstructure as affected by different tillage systems and their effects on maize root growth. Soil Tillage Res. 140, 55-65. doi:http://dx.doi.org/10.1016/j. still.2014.02.003.

EMBRAPA, 1997. Manual de Métodos de Análise de Solos (Handbook of Soil Analysis Methods), 2nd ed. EMBRAPA - CNPS, Rio de Janeiro.

EMBRAPA, 2013. Sistema Brasileiro de Classificação de Solos (Brazilian System of Soil Classification), 3rd ed. EMBRAPA - CNPS, Rio de Janeiro.

Elliot, T.R., Heck, R.J., 2007. A comparison of 2D vs 3D thresholding of X-ray CT imagery. Can. J. Soil Sci. 87, 405-412. doi:http://dx.doi.org/10.4141/cjss2012 044.

FAO, 1998. World Reference Base for Soil Resources (No 84). Food and Agriculture Organization of the United States. FAO, ISRIC and ISSS, Italy.

Fox, D., Bryan, R., Fox, C., 2004. Changes in pore characteristics with depth for structural crusts. Geoderma 120, 109-120. doi:http://dx.doi.org/10.1016/j. geoderma.2003.08.010.

GE Healthcare, 2006. eXplore Locus User Guide, TechnicalPublication Direction 2394683 Revision 1a: 1-73.

Genro Junior, S.A., Reinert, D.J., Reichert, J.M., 2004. Variabilidade temporal da resistência à penetração de um latossolo argiloso sob semeadura direta com rotação de culturas (Temporal variation of soil penetration resistance in a clayey oxisol under no-tillage and crop rotation). Rev. Bras. Ciência do Solo 28, 477484. doi:http://dx.doi.org/10.1590/S0100-06832004000300009 in Portuguese, with English abstract.

Greenland, D.J., Pereira, H.C., 1977. Soil damage by intensive arable cultivation: temporary or permanent? [and discussion]. Philos. Trans. R. Soc. B Biol. Sci. 281, 193-208. doi:http://dx.doi.org/10.1098/rstb.1977.0133.
Guérif, J., Richard, G., Dürr, C., Machet, J., Recous, S., Roger-Estrade, J., 2001. A review of tillage effects on crop residue management, seedbed conditions and seedling establishment. Soil Tillage Res. 61, 13-32. doi:http://dx.doi.org/10.1016/S01671987(01)00187-8.

Hajnos, M., Lipiec, J., Świeboda, R., Sokołowska, Z., Witkowska-Walczak, B., 2006 Complete characterization of pore size distribution of tilled and orchard soil using water retention curve, mercury porosimetry, nitrogen adsorption, and water desorption methods. Geoderma 135, 307-314. doi:http://dx.doi.org/ 10.1016/j.geoderma.2006.01.010.

Heck, R.J., 2009. X-ray computed tomography of soil. In: Ribeiro, M.R., Nascimento, C.W., do Filho, M.R.R., Cantalice, J.R.B. (Eds.), Tópicos Em Ciência Do Solo (Topics in Soil Science). SBCS, Viçosa, pp. 31-70.

Helliwell, J.R., Sturrock, C.J., Grayling, K.M., Tracy, S.R., Flavel, R.J., Young, I.M., Whalley, W.R., Mooney, S.J., 2013. Applications of X-ray computed tomography for examining biophysical interactions and structural development in soil systems: a review. Eur. J. Soil Sci. 64, 279-297. doi:http://dx.doi.org/10.1111/ ejss.12028.

Hillel, D., 1998. Environmental Soil Physics: Fundamentals, Applications, and Environmental Considerations. Academic Press, London.

Hussain, I., Olson, K.R., Siemens, J.C., 1998. Long-term tillage effects on physical properties of eroded soil. Soil Sci. 163, 970-981. doi:http://dx.doi.org/10.1097/ 00010694-199812000-00007.

Imhoff, S., Ghiberto, P.J., Grioni, A., Gay, J.P., 2010. Porosity characterization of Argiudolls under different management systems in the Argentine Flat Pampa. Geoderma 158, 268-274. doi:http://dx.doi.org/10.1016/j. geoderma.2010.05.005.

Jefferies, D.A., Heck, R.J., Thevathasan, N.V., Gordon, A.M., 2014. Characterizing soil surface structure in a temperate tree-based intercropping system using X-ray computed tomography. Agrofor. Syst. 88, 645-656. doi:http://dx.doi.org/ 10.1007/s10457-014-9699-0.

Jefferies, D.A., 2014. X-ray Computed Micro-Tomography Indices of Soil Microstructure Within a Tree-Based Intercropping System Doctoral Thesis. University of Guelph, Guelph, pp. 119.

Jury, W.A., Horton, R.C.N., 2004. Soil Physics, 6th ed. John Wiley, Hoboken, NJ, USA.

Kastanek, F.J., Nielsen, D.R., 2001. Description of soil water characteristics using cubic spline interpolation. Soil Sci. Soc. Am. J. 65, 279. doi:http://dx.doi.org/ 10.2136/sssaj2001.652279x.

Kay, B., VandenBygaart, A., 2002. Conservation tillage and depth stratification of porosity and soil organic matter. Soil Tillage Res. 66, 107-118. doi:http://dx.doi. org/10.1016/S0167-1987(02)00019-3.

Klute, A., 1986. Water retention: laboratory methods. In: Klute, A. (Ed.), Methods of Soil Analysis: Part 1-Physical and Mineralogical Methods. American Society of Agronomy, Soil Science Society of America Book Series, Madison, pp. 635-662.

Kodešová, R., Jirkû, V., Kodeš, V., Mühlhanselová, M., Nikodem, A., Žigová, A., 2011 Soil structure and soil hydraulic properties of Haplic Luvisol used as arable land and grassland. Soil Tillage Res. 111, 154-161. doi:http://dx.doi.org/10.1016/j. still.2010.09.007.

Kodesova', R., Koca'rek, M., Kodes, V., Simunek, J., Koza'k, J., 2008. Impact of soil micromorphological features on water flow and herbicide transport in soils. Vadose Zo. J. 7, 798-809. doi:http://dx.doi.org/10.2136/vzj2007.0079.

Kravchenko, A.N., Wang, A.N.W., Smucker, A.J.M., Rivers, M.L., 2011. Long-term differences in tillage and land use affect intra-aggregate pore heterogeneity. Soil Sci. Soc. Am. J. 75, 1658. doi:http://dx.doi.org/10.2136/sssaj2011.0096.

Kutílek, M., Nielsen, D.R., 1994. Soil Hydrology. Catena Verlag, Germany.

Kutílek, M., 2004. Soil hydraulic properties as related to soil structure. Soil Tillage Res. 79, 175-184. doi:http://dx.doi.org/10.1016/j.still.2004.07.006.

Kutilek, M., Jendele, L., Panayiotopoulos, K., 2006. The influence of uniaxial compression upon pore size distribution in bi-modal soils. Soil Tillage Res. 86, 27-37. doi:http://dx.doi.org/10.1016/j.still.2005.02.001.

Lal, R., Shukla, M.K., 2004. Principles of Soil Physics. CRC Press, New York.

Lima, H.V., de Lima, C.L.R., de Leão, T.P., Cooper, M., Silva, A.P., da Romero, R.E., 2005. Trãfego de mãquinas agrácolas e alteraíçes de bioporos em ãrea sob pomar de laranja (Agricultural machinery traffic and alterations in biopores under an orange orchard). Rev. Bras. Ciência do Solo 29, 677-684. doi:http://dx.doi.org $10.1590 /$ S0100-06832005000500003 in Portuguese,with English abstract.

Lipiec, J., Kuś, J., Słowińska-Jurkiewicz, A., Nosalewicz, A., 2006. Soil porosity and water infiltration as influenced by tillage methods. Soil Tillage Res. 89, 210-220. doi:http://dx.doi.org/10.1016/j.still.2005.07.012.

Lipiec, J., Walczak, R., Witkowska-Walczak, B., Nosalewicz, A., SłowińskaJurkiewicz, A., Sławiński, C., 2007. The effect of aggregate size on water retention and pore structure of two silt loam soils of different genesis. Soil Tillage Res. 97, 239-246. doi:http://dx.doi.org/10.1016/j.still.2007.10.001.

Marcolan, A.L., Anghinoni, I., 2006. Physical attributes of an ultisol and crop yield as affected by soil mobilization in no-tillage system. Rev. Bras. Ciência do Solo 30, 163-170. doi:http://dx.doi.org/10.1590/S0100-06832006000100016.

Martins, T., Saab, S.C., Milori, D., Brinatti, A.M., Rosa, J.A., Cassaro, F.A.M., Pires, L.F. 2011. Soil organic matter humification under different tillage managements evaluated by Laser Induced Fluorescence (LIF) and C/N ratio. Soil Tillage Res. 111 231-235. doi:http://dx.doi.org/10.1016/j.still.2010.10.009.

Ogunwole, J.O., Pires, L.F., Shehu, B.M., 2015. Changes in the structure of a nigerian soil under different land management practices. Rev. Bras. Ciência do Solo 39, 830-840. doi:http://dx.doi.org/10.1590/01000683rbcs20140017.

Osunbitan, J.A., Oyedele, D.J., Adekalu, K.O., 2005. Tillage effects on bulk density, hydraulic conductivity and strength of a loamy sand soil in southwestern Nigeria. Soil Tillage Res. 82, 57-64. doi:http://dx.doi.org/10.1016/j. still.2004.05.007. 
Pagenkemper, S.K., Athmann, M., Uteau, D., Kautz, T., Peth, S., 2015. The effect of earthworm activity on soil bioporosity-investigated with X-ray computed tomography and endoscopy. Soil Tillage Res. 146, 79-88. doi:http://dx.doi.org/ 10.1016/j.still.2014.05.007.

Pagliai, M., Vignozzi, N., 2002. The pore system as an indicator of soil quality. In: Pagliai, M., Jones, R. (Eds.), Sustainable Land Management-Environmental Protection-A Soil Physical Approach. Advances in Geoecology. Catena Verlag, Reiskirchen, pp. 71-82.

Pagliai, M., La Marca, M., Lucamante, G., Genovese, L., 1984. Effects of zero and conventional tillage on the length and irregularity of elongated pores in a clay loam soil under viticulture. Soil Tillage Res. 4, 433-444. doi:http://dx.doi.org/ 10.1016/0167-1987(84)90051-5.

Pagliai, M., Vignozzi, N., Pellegrini, S., 2004. Soil structure and the effect of management practices. Soil Tillage Res. 79, 131-143. doi:http://dx.doi.org/ 10.1016/j.still.2004.07.002.

Passoni, S., Pires, L.F., Heck, R., Rosa, J.A., 2015. Three dimensional characterization of soil macroporosity by X-ray microtomography. Rev. Bras. Ciência do Solo 39, 448-457. doi:http://dx.doi.org/10.1590/01000683rbcs20140360.

Peth, S., Horn, R., Beckmann, F., Donath, T., Fischer, J., Smucker, A.J.M., 2008. Threedimensional quantification of intra-aggregate pore-space features using synchrotron-radiation-based microtomography. Soil Sci. Soc. Am. J. 72, 897. doi: http://dx.doi.org/10.2136/sssaj2007.0130.

Pires, L.F., Cooper, M., Cássaro, F.A.M., Reichardt, K., Bacchi, O.O.S., Dias, N.M.P., 2008. Micromorphological analysis to characterize structure modifications of soil samples submitted to wetting and drying cycles. Catena 72, 297-304. doi: http://dx.doi.org/10.1016/j.catena.2007.06.003.

Pires, L.F., Borges, J.A.R., Bacchi, O.O.S., Reichardt, K., 2010. Twenty-five years of computed tomography in soil physics: a literature review of the Brazilian contribution. Soil Tillage Res. 110, 197-210. doi:http://dx.doi.org/10.1016/j. still.2010.07.013.

Pires, L.F., Borges, F.S., Passoni, S., Pereira, A.B., 2013. Soil pore characterization using free software and a portable optical microscope. Pedosphere 23, 503-510. doi: http://dx.doi.org/10.1016/S1002-0160(13)60043-0.

Portella, C.M.R., Guimarães, M., de, F., Feller, C., Fonseca, I.C., de, B., Tavares Filho, J. 2012. Soil aggregation under different management systems. Rev. Bras. Ciência do Solo 36, 1868-1877. doi:http://dx.doi.org/10.1590/S010006832012000600021.

Quinton, W.L., Elliot, T., Price, J.S., Rezanezhad, F., Heck, R., 2009. Measuring physical and hydraulic properties of peat from X-ray tomography. Geoderma 153, 269277. doi:http://dx.doi.org/10.1016/j.geoderma.2009.08.010.

Rab, M.A., Haling, R.E., Aarons, S.R., Hannah, M., Young, I.M., Gibson, D., 2014. Evaluation of X-ray computed tomography for quantifying macroporosity of loamy pasture soils. Geoderma 213, 460-470. doi:http://dx.doi.org/10.1016/j. geoderma.2013.08.037.

Rasband, W., 2007. ImageJ. 1997-2007. U.S. National Institutes of Health, Bethesda MD, USA http://rsb.info.nih.gov/ij/ (accessed 01.04.14).

Reichert, J.M., Suzuki, L.E.A.S., Reinert, D.J., 2007. Compactação do solo em sistemas agropecuários e florestais: identificação, efeitos, limites críticos e mitigação (Soil compaction in agricultural and forestry systems: identification, effects, critical limits and mitigation). In: Ceretta, C.A., Silva, L.S., Reichert, J.M. (Eds.) Topics in Soil Science. Brazilian Society of Soil Science, Viçosa, pp. 49-134.

Reichert, J.M., Suzuki, L.E.A.S., Reinert, D.J., Horn, R., Håkansson, I., 2009. Reference bulk density and critical degree-of-compactness for no-till crop production in subtropical highly weathered soils. Soil Tillage Res. 102, 242-254. doi:http://dx. doi.org/10.1016/j.still.2008.07.002.

Rezanezhad, F., Quinton, W.L., Price, J.S., Elrick, D., Elliot, T.R., Heck, R.J., 2009. Examining the effect of pore size distribution and shape on flow through unsaturated peat using computed tomography. Hydrol. Earth Syst. Sci. 13, 19932002. doi:http://dx.doi.org/10.5194/hess-13-1993-2009.

Roque, W.L., Souza, A.C.A., Barbieri, de, 2009. The Euler-Poincaré characteristic applied to identify low bone density from vertebral tomographic images. Rev. Bras. Reumatol. 49, 140-145. doi:http://dx.doi.org/10.1590/s048250042009000200006.

Roque, W.L., Arcaro, K., Alberich-Bayarri, A., 2012a. Tortuosity and elasticity study of distal radius trabecular bone. In: Rocha, Á., Calvo-Manzano, J.A., Reis, L.P., Cota, M.P. (Eds.), Sistemas Y Tecnologías de Información: Actas de La $7^{a}$ Conferencia Ibérica de Sistemas Y Tecnologías de Información. APPACDM - Associação Portuguesa de Pais e Amigos do Cidadão Deficiente Mental, Madrid, pp. 1-4

Roque, W.L., Arcaro, K., Lanfredi, R.B., 2012b. Trabecular network tortuosity and connectivity of distal radius from microtomographic images. Braz. J. Biomed. Eng. 28, 116-123. doi:http://dx.doi.org/10.4322/rbeb.2012.017.

Schjønning, P., Rasmussen, K.J., 2000. Soil strength and soil pore characteristics for direct drilled and ploughed soils. Soil Tillage Res. 57, 69-82. doi:http://dx.doi. org/10.1016/S0167-1987(00)00149-5.

Schlüter, S., Weller, U., Vogel, H.-J., 2010. Segmentation of X-ray microtomography images of soil using gradient masks. Comput. Geosci. 36, 1246-1251. doi:http:// dx.doi.org/10.1016/j.cageo.2010.02.007.

Soil Survey Staff, 1998. Keys to Soil Taxonomy, 8th ed. USDA, Washington.

Sterio, D.C., 1984. The unbiased estimation of number and sizes of arbitrary particles using the disector. J. Microsc.134, 127-136. doi:http://dx.doi.org/10.1111/j.13652818.1984.tb02501.x.

Taina, I.A., Heck, R.J., Elliot, T.R., Scaiff, N., 2010. Micromorphological and X-ray (CT study of Orthic Humic Gleysols under different management conditions. Geoderma 158,110-119. doi:http://dx.doi.org/10.1016/j.geoderma.2010.02.009.

Taina, I.A. Heck, R.J., Deen, W.. Ma, E.Y.T., 2013. Quantification of freeze-thaw related structure in cultivated topsoils using X-ray computer tomography. Can. J. Soil Sci. 93, 533-553. doi:http://dx.doi.org/10.4141/cjss2012-044.

Tavares Filho, J., Tessier, D., 2009. Characterization of soil structure and porosity under long-term conventional tillage and no-tillage systems. Rev. Bras. Ciência do Solo 33, 1837-1844. doi:http://dx.doi.org/10.1590/S010006832009000600032 .

Thurston, W.P., 1997. Three-dimensional Geometry and Topology, 1st ed. Princeton University Press, Princeton.

Tuller, M., Or, D., 2002. Unsaturated hydraulic conductivity of structured porous media: a review of liquid configuration-based models. Vadose Zo. J. 1, 14-37. doi:http://dx.doi.org/10.2113/1.1.14.

Tuzzin de Moraes, M., Debiasi, H., Carlesso, R., Cezar Franchini, J., Rodrigues da Silva, V., Bonini da Luz, F., 2016. Soil physical quality on tillage and cropping systems after two decades in the subtropical region of Brazil. Soil Tillage Res. 155, 351362. doi:http://dx.doi.org/10.1016/j.still.2015.07.015.

Udawatta, R.P., Anderson, S.H., Gantzer, C.J., Garrett, H.E., 2006. Agroforestry and grass buffer influence on macropore characteristics. Soil Sci. Soc. Am. J. 70, 1763. doi:http://dx.doi.org/10.2136/sssaj2006.0307.

Zaffar, M., Lu, S.-G., 2015. Pore size distribution of clayey soils and its correlation with soil organic matter. Pedosphere 25, 240-249. doi:http://dx.doi.org/ 10.1016/S1002-0160(15)60009-1. 